\title{
THE
}

COPYRIGHT

PENTALOGY

HOW THE

SUPREME COURT

OF CANADA

SHOOK THE

FOUNDATIONS OF

CANADIAN

COPYRIGHTLAW

EDITED BY

MICHAEL GEIST 
Ariel Katz, "Fair Use 2.0: The Rebirth of Fair Dealing in Canada", in The Copyright Pentalogy: How the Supreme Court of Canada Shook the Foundations of Canadian Copyright Law, Michael Geist, ed., pp 93-156 (Ottawa, ON: Ottawa University Press, 2013)

(c) Ariel Katz, 2013 under Creative Commons License Attribution-Non Commercial Share Alike 3.0 (CC BYNC-SA 3.0) http://creativecommons.org/licenses/by-nc$\mathrm{sa} / 3.0 /$ 


\title{
() \\ Fair Use 2.0: \\ The Rebirth of Fair Dealing in Canada
}

\author{
ARIEL KATZ ${ }^{1}$
}

\section{I: Introduction}

A century ago, on 16 December 1911, the UK Copyright Act, 1911 received royal assent, and for the first time fair dealing was explicitly recognized in the imperial copyright legislation. ${ }^{2}$ Ten years later, the same fair dealing provision would appear in the Canadian Copyright Act, 1921 and would remain the basis of the current fair dealing provisions. Tragically, what was supposed to be an exercise in the codification of a dynamic and evolving commonlaw principle, usually referred to as "fair use", ended up-with a few notable exceptions - in a hundred years of solitude and stagnation. Misinterpreting the 1911 Act, some courts and commentators in many Commonwealth jurisdictions adopted a narrow and restrictive view of fair dealing. Meanwhile, in the United States, fair use, the same common law rule developed by English and American courts, remained uncodified for most of the twentieth century, and when the United States finally codified it in 1976, Congress left no doubt that the codification would not alter its common law basis and ought not hinder its flexibility and adaptability. Thus, toward the end of the twentieth century, a noticeable split in Anglo-American copyright 
law emerged: an omnipresent, flexible fair use regime in the United States, and a seemingly rigid and restrictive fair dealing tradition in the Commonwealth countries.

However, at the turn of the twenty-first century, fair dealing was reborn in Canada. In 2004 the Supreme Court of Canada heard CCH Canadian Ltd. v Law Society of Upper Canada [CCH], ${ }^{4}$ its firstever case involving fair dealing, and unanimously declared that fair dealing is a users' right, which is as integral to copyright law as the rights of copyright owners and therefore should be given large and liberal interpretation. ${ }^{5}$ Eight years later, the Court rejected attempts to roll back its earlier decision and handed down two judgments reaffirming its holdings from $\mathrm{CCH}$ and clarifying that they apply to a wider range of activities. -6 In doing so, the Court corrected a centurylong misconception of fair dealing, reunited it with its historical roots, and brought it closer to its American counterpart. Moving in the same direction, and shortly before the Supreme Court handed down its judgments, the Parliament of Canada passed the Copyright Modernization Act, which explicitly recognized education, parody and satire as purposes that could qualify as fair dealing, - and added a series of other specific exceptions, dealing with issues such as usergenerated content, copying for private purposes, time-shifting or temporary copying..

Still, both the Court and Parliament stopped short of explicitly adopting of an open-ended approach to fair dealing, seemingly unable to decide whether Canada is better off clinging to a burdensome colonial British past or embracing an imperfect (North) American present. This chapter shows, however, that this dilemma is false: while fair dealing has ossified under current British law,,- the colonial copyright past that Canada inherited is not quite as burdensome as it is commonly perceived to be. On some measures, Canada has already improved upon the present American model of fair use, yet it still seems hesitant to fully embrace its most important and salient feature: its open-endedness. But Canada is now poised to fully embrace an open-ended fair dealing, and there are very good reasons for doing that. It can and should upgrade from Fair Dealing 1.9 to Fair Use 2.0.

The chapter will recount the history of fair use and fair dealing and show that, contrary to conventional wisdom, the enactment of 
the Imperial Copyright Act of 1911-and subsequently the enactment of the Canadian Copyright Act of 1921-was not designed to cause any major alteration in the common law of fair dealing, and the explicit recognition of five enumerated purposes in the (then) newly enacted fair dealing provision was not intended to limit the principle of fair dealing exclusively to those five purposes. Moreover, despite abundant contemporary literature that highlights a seeming dichotomy between the open-ended US-style fair use, and the supposedly close-ended fair dealing, 10 this dichotomy is false. The question of whether the list of enumerated purposes is exhaustive or, instead, illustrative of a broader principle has never been put squarely before the courts, let alone the higher courts, and certainly not in Canada. Similarly, no court has ever confronted the question of whether the common law fair use doctrine that existed before 1911 continues to coexist with the statutory fair dealing. Therefore, the question of whether fair dealing in Canada can apply to purposes that are not explicitly mentioned in the Copyright Act is an open one, and as this chapter shows, can and should be answered affirmatively. Doing so will not transplant a foreign legal concept, as some have argued. $\frac{11}{}$ Rather, it will reunite present copyright doctrine with its rich and historic roots that were latent but never discarded. Embracing an open-ended fair dealing is the only logical application of the Court's decisions and Parliament's action, and the only interpretation of the Act that can be internally, historically and constitutionally coherent.

\section{II: The Fair Use vs. Fair Dealing Myth}

According to conventional wisdom, a fundamental difference exists between the American fair use doctrine and the Canadian fair dealing doctrine. American fair use can apply potentially to any purposes, and the enumerated purposes in section 107 of the US Copyright Act are only illustrative, as is clear from the explicit words "such as". 12 In contrast, ss 29 and 29.1 of the Canadian Copyright Act, like other descendants of the 1911 UK Copyright Act, do not contain the magic words "such as", and therefore, the list of enumerated purposes (originally: research, private study, criticism, review or newspaper summary, $\underline{13}$ and currently: research, private study, education, parody, 
satire, criticism, review or news reporting) ${ }^{14}$ is treated as exhaustive..$^{15}$ Accordingly, the argument goes, "[d]ealings for other purposes are not covered by the exception, even if they would otherwise be fair." 16

As the following parts show in greater detail, this conventional wisdom is flawed. The 1911 codification of fair dealing was not meant to limit its application to those five enumerated purposes. Moreover, the question of whether the list is indeed exhaustive has never been, as far as I know, put squarely before the courts, let alone the highest courts, neither in Canada nor in any other Commonwealth jurisdiction. Some courts assumed that the list is exhaustive, and judicial dicta and commentary supporting this proposition can easily be found, but the proposition that the list of allowable purposes is exhaustive has never been the ratio of any decided and reported case. In other words, there is no reported case in which a defendant, who dealt with a work in a manner that would be considered fair under the fairness factors developed by the courts, was found to be infringing nonetheless, solely on the basis that the dealing could not fit into any of the enumerated categories..$^{17}$ Moreover, cases in other Commonwealth jurisdictions that may come close to that situation sometimes prompted ad hoc legislative amendments, and in any event were based on a pre- $\mathrm{CCH}$ conception: namely, that fair dealing is an exception that should be interpreted narrowly. $\frac{18}{\text { Therefore, these }}$ cases are of limited utility in post- $\mathrm{CCH}$ Canada. $\underline{19}$

A related misconception is that distinct histories and origins of Canadian and American copyright laws, as well as differences in their constitutional foundations, reflect disparate conceptions of copyright and hence justify, or at least explain, differences in substantive rules. A representative example of a claim about distinct history and origin is Estey J's remark in Compo v. Blue Crest that despite many similarities between the copyright acts of both countries, "United States court decisions, even where the factual situations are similar, must be scrutinized very carefully because of some fundamental differences in copyright concepts which have been adopted in the legislation of that country." 20 According to Estey J, the Canadian legislation has been based on the international copyright treaties of the nineteenth and twentieth centuries, whereas the American legislation was not. 11 This historical account is highly inaccurate, as the copyright acts 
of both countries are descendants of the Statute of Anne and the jurisprudential developments that followed in Britain and the US. The international treaties may explain some differences and later developments, but those treaties have not altered the fundamental concepts and key doctrines.

Attributing differences in the area of fair dealing to differences in the constitutional foundations is equally flawed. The US Constitution empowers Congress "To promote the Progress of Science and useful Arts, by securing for limited Times to Authors and Inventors the exclusive Right to their respective Writings and Discoveries"22, and this clause is generally understood to impose some limitations on Congressional legislative power in this area. $\frac{23}{}$ In contrast, the argument goes, the Constitution Act, 1867 [previously known as the British North America Act] gives the Parliament of Canada exclusive jurisdiction over Patents of Invention and Discovery (s 91(22)), and over Copyrights (s 91(23)), , but mentions no substantive limitation on the content of such laws.

However, the lack of language similar to that of the US Constitution does not necessarily imply any differences in how copyright (and patent) laws were conceived when those constitutional documents were drafted. ${ }^{25}$ Indeed, the notion that purpose of copyright and patent laws is to promote progress of science and the useful arts was not invented by the Framers of the US Constitution, but rather reflected the common conception of the era. It is easy to see that the title of the Statute of Anne, the first copyright statute, contained the three elements found in the American Constitutional clause. The Act's long title was An act for the encouragement of learning, by vesting the copies of printed books in the authors or purchasers of such copies, during the times therein mentioned. Both combine a public policy goal (compare "For the encouragement of learning" and "to promote the Progress of Science"); to be achieved by granting private exclusive rights (compare "by vesting the copies of printed books in the authors or purchasers of such copies" and "by securing...to Authors exclusive Right to their... Writings"); and a duration limitation (compare: "during the times therein mentioned" and "for limited Times"). $\underline{\underline{26}}$

The idea of "progress" was a buzzword in the eighteenth century ${ }^{27}$ and reflected the contemporaneous ideals of the Enlightenment. $\frac{28}{}$ 
While the US Constitution might be considered as one of the highlights of the Enlightenment, $\frac{29}{9}$ those ideals were not invented by the Framers and did not originate in the American colonies. Those ideas were prevalent in Britain, and it is not surprising that they would also appear in contemporaneous English judicial decisions.

In 1785 (four years before the adoption of the US Constitution), Lord Mansfield warned that

[w] e must take care to guard against two extremes equally prejudicial; the one, that men of ability, who have employed their time for the service of the community, may not be deprived of their just merits, and the reward of their ingenuity and labour; the other, that the world may not be deprived of improvements, nor the progress of the arts be retarded. ${ }^{30}$

And in 1802, Lord Ellenborough wrote that "a man may fairly adopt part of the work of another: he may so make use of another's labours for the promotion of science, and the benefit of the public." 11 And when in 1842, the Statute of Anne was repealed and replaced with a new Copyright Act, section 1 of that Act used similar language, evoking similar ideas, and recited that it was "expedient to amend the law of copyright, and to afford greater encouragement to the production of literary works of lasting benefit to the world." 32

Thus, when Souter J of the US Supreme Court explained that "[f]rom the infancy of copyright protection, some opportunity for fair use of copyrighted materials has been thought necessary to fulfill copyright's very purpose, ' $[\mathrm{t}$ ]o promote the Progress of Science and useful Arts..."” 33 his historical account of fair use was as accurate with respect to American law as it was true to English and Canadian law, notwithstanding the absence of explicit "progress" language in Anglo-Canadian constitutional documents. $\frac{34}{}$

Likewise, the notion that copyrights, like patents for inventions, were limited grants of statutory exclusive rights, justified in the name of the public interest, was common to both jurisdictions, and evolved in corresponding steps in Britain and the US. Why the British North America Act chose the terms "copyright" and "patents of invention and discovery" without adding any limiting language such as can 
be found in the US Constitution is beyond the scope of this chapter. A possible answer, however, is that by 1867, the terms "copyright" and "patents of invention and discovery" already embodied an established meaning containing the inherent limitations on duration and purpose. .5 This meaning harks back at least to Darcy $v$ Allen from $1603^{36}$ and the Statute of Monopolies from 1624. $\frac{37}{}$ As Bracha writes,

By the end of the eighteenth century, the principle of limited duration of monopolies had been a staple of English political thought for two centuries. According to this principle, monopolies usually seen as reprehensible could be tolerated in exceptional cases where they served the public good, provided the monopolies were kept within certain safeguards. Chief among these safeguards was limited duration. $\underline{38}$

While the applicability of this principle to patents of invention was beyond debate, it took longer for the law to settle on this point in the case of copyrights, where a competing vision of copyright as perpetual common law property right lingered until eventually being laid to rest, first in Britain and later in the US.

After the expiry of the statutory terms provided in the Statute of Anne, the London book publishers continued to assert that they had a perpetual common law copyright, which was not affected by the Statute. In Millar v. Taylor ${ }^{39}$ the King's Bench agreed. Five years later, however, in Donaldson $v$ Beckett, t0 $^{40}$ the House of Lords reached a different conclusion. $\underline{41}$ The traditional account is that the House of Lords held that there was a common law right of first publication, replaced by the limited-term statutory copyright after publication, although doubts about that continued to linger. $\underline{42}$ In 1854, however, in Jeffreys $v$ Boosey, , $^{43}$ the House of Lords handed down another decision rejecting the notion of a common law property right whose nature was akin to the statutory protection first established by the Statute of Anne. $\underline{44}$ If any rights existed prior to publication, they were no more than an incident of the author ownership of the tangible manuscript, but not "copyright". Copyright, in contrast, was a pure creature of statute. ${ }^{45}$ To remove any doubt, the issue was finally settled when the 1911 Act abrogated any common law copyright that might have 
existed, and applied statutory copyright indiscriminately to published and unpublished works.

What prompted the Framers of the US Constitution in 1789 to include the specific language in cl. 8 is not entirely clear, and what their precise intention was is equally obscure. $\frac{46}{\text { In }}$ any event, incorporating these limitations into the US Constitution did not prevent a competing narrative of common law copyright from emerging. As in Britain, the issue was finally settled by legislation, with the passage of section 301 of the Copyright Act in 1976, pre-empting all state laws creating or recognizing, as a matter of state statutes or common law, rights equivalent to those within the scope of the Act. $\stackrel{47}{ }$

The lack of similar language in the Constitution Act is very poor indication for fundamental differences in the conception of copyright between the two countries. If the language of the US Constitution was meant to limit legislative power, the absence of similar language in the Constitution Act is not surprising, because explicit limits on state power are a key feature of the American constitutional design.. In contrast, Canada's Constitution Act is premised on the British concept of parliamentary omnipotence, and its core objective has been the division of theoretically unlimited legislative power between the Dominion of Canada and the Provinces. Moreover, the Statute of Anne did not use the term "copyright", and although the term had already been in use by the end of the eighteenth century, the language in the US Constitution might have been adopted simply to describe the mandate that was given to Congress. It would be unnecessary to do the same in Canada because by 1867, the meaning of the terms "copyrights" and "patents of invention and discovery" had already been established.

In sum, the claim that differences between American fair use and Canadian fair dealing arise from different constitutional structures reflecting divergent ideological views about copyright does not have any serious historic support.

\section{III: The History of Fair Dealing}

This part describes the history of fair dealing, from its emergence as a common law doctrine to its first statutory appearance in section 
2(1)(i) of the Copyright Act, 1911 in the UK, and subsequently, in section 16 of the Copyright Act, 1921 in Canada.

\section{A. Common Law Origins}

Fair use and fair dealing were not born by statute but developed as judge-made law, first by English and then by American judges, who mutually influenced and cross-referenced each other. ${ }^{49}$ The prehistory of fair use and fair dealing has been documented by several scholars ${ }^{50}$ and needs not be repeated here fully, but a few highlights are worth mentioning. First, as Patry writes, "unlike Athena, the doctrine of fair use did not spring forth fully formed." and contours developed gradually, although "the basic foundation and rationale were established remarkably early." ${ }^{52}$ By 1841, when the doctrine made its full appearance in the United States in Folsom $v$ Marsh,$\underline{53}$ American courts already had a hundred years of English case law to draw upon..$\underline{54}$ During the nineteenth century, fair use was a broad concept that encompassed several issues that today would often be treated separately: for example, it would apply to the copying of non-protectable facts and ideas as distinct from protectable expressions,,$\frac{55}{5}$ to the copying of non-substantial parts of protected expressions, $\frac{56}{6}$ as well as to permissible copying of substantial parts of protected expressions. While current doctrine tends to treat these issues as conceptually distinct, and confine fair dealing to the third, the three are not entirely separate. The tests used for determining "substantiality" involve similar questions to those that are asked in determining "fairness", 57 and whether the work is mainly factual or expressive may influence the outcome of the fairness analysis. $\frac{58}{}$

Second, the common terminology in English copyright law prior to 1911 was often "fair use,, just like the American terminology, but it was also common to use the term "fair" as an adjective to describe specific activities, such as "fair quotation", 60 "fair criticism", "fair refutation", 16 and, in the earlier cases, "fair abridgement". ${ }^{62}$ Sometimes courts would not use the term "fair" but its synonyms, such as "bona fide imitations, translations and abridgements." $\underline{63}$ The switch to "fair dealing" in Commonwealth jurisdictions seems to simply follow a terminology adopted when the doctrine was codified in 1911, $\underline{\underline{6}}$ but, as will be discussed in greater detail below, there is no evidence that 
the switch from "use" to "dealing" was intended to reflect any change in the law or its direction. $\underline{65}$

Third, the English judges who created fair use should not necessarily be seen as champions of users' rights and the public interest reining in overly expansive copyrights—as might be seen through contemporary spectacles. Rather, recognizing fair use allowed judges to actively expand the scope of copyright protection, beyond the original exclusive right to print or reprint books. $\underline{66}$ "By starting with the unobjectionable proposition that making a merely colourable alteration to an earlier work would not be sufficient to avoid the statute, the courts were able to expand copyright protection well beyond cases that could meaningfully be described as a case of reprinting." 67

Still, even before the Supreme Court of Canada declared in $\mathrm{CCH}$ that fair dealing is a "users' right", $\underline{6}$ courts and commentators often referred to the ability to use another's work without permission as a users' right, and employed the term "the right of fair user". ${ }^{69}$ Similarly, the connection between fair use, the scope of protection, and the public interest was not invented in $\mathrm{CCH}$, but had been recognized two centuries earlier. $\stackrel{70}{ }$ For example, in Cary $v$ Kearsley, decided in 1802, Lord Ellenborough CJ explained that

a man may fairly adopt part of the work of another: he may so make use of another's labours for the promotion of science, and the benefit of the public; but having done so, the question will be, Was the matter so taken used fairly with that view, and without what I may term the animus furandi?

Then, after further elaboration, he put the question for the jury to consider as

whether what so taken or supposed to be transmitted from the plaintiff's book, was fairly done with a view of compiling a useful book, for the benefit of the public, upon which there has been a totally new arrangement of such matter-or taken colourable, merely with a view to steal the copy-right of the plaintiff? 
Therefore, to the extent that $\mathrm{CCH}$ may be seen as revolutionary, it is only revolutionary when viewed through a very narrow historical lens, but viewing it with a broader historical perspective suggests that if $\mathrm{CCH}$ departed from earlier case law, it only brought back the law to its historical path.

\section{B. The Codification of Fair Use}

Fair use remained a common-law principle in the UK until the enactment of the Copyright Act, 1911, which for the first time included a statutory fair dealing provision. Section 2(1)(i) of the 1911 Act provided that "Any fair dealing with any work for the purposes of private study, research, criticism, review, or newspaper summary" shall not constitute an infringement of copyright. It was supplemented by additional, specifically tailored exceptions. The same provision would appear a decade later in Canada, and its language would remain unchanged until 1993 (when attribution requirements were added to criticism, review and newspaper summary), $\underline{ }$ and 1997 (when "newspaper summary" was replaced with the wider "news reporting", the phrase "private study or research" was modified to "research or private study", apparently to pre-empt an interpretation that would limit research to private settings, $\underline{73}$ and the reference to "work" was deleted to expand fair dealing to sound recordings, performers' performances and communication signals, $\underline{\underline{ }}$ and again in 2012 (when "education, parody, and satire" were added alongside research and private study). In the US, the doctrine remained uncodified until 1976.

As noted above, conventional wisdom holds that the enactment created an exhaustive list of allowable purposes. However, this view is biased by hindsight. It confuses a narrow (and, as we shall see below, erroneous) subsequent interpretation of the 1911 Act with the intended effect of the 1911 codification, and it also wrongly deduces from the inclusion by US Congress of the explicit words "such as", that their absence from the UK 1911 legislation necessarily reflects Parliament's desire to limit fair dealing to the enumerated purposes. As I explain below, a small number of early English courts misinterpreted Parliament's intent, adopting a restrictive but erroneous view of fair dealing, which has never been seriously challenged. Moreover, the 
legislative history of section 107 in the US indicates that the decision of Congress to add the words "such as" reflects a lesson learned from the British earlier exercise in codification. $\underline{75}$

\section{Fair Dealing's Decline}

In retrospect, it appears that the first attempt to legislate fair dealing has not been successful. A few early cases have set the law of fair dealing in the UK and the Commonwealth on a restrictive trajectory from which it has not yet recovered. This has also been the case of Canada, at least until the recent rulings of the Supreme Court. Of these cases, University of London Press, British Oxygen, and Hawkes and Son are particularly noteworthy: the first, not for what it actually held, but for how it had been misinterpreted, and the other two for their holding and reasoning. ${ }^{76}$ Overall, with some exceptions, these decisions set the tone for a castrated version of fair dealing, first by confining fair dealing to the list of enumerated purposes and then by construing them narrowly. $\underline{\cdot 7}$

\section{University of London Press}

University of London Press Ltd $v$ University Tutorial Press Ltd. $\underline{78}$ was one of the first reported cases decided under the 1911 Act, and the first case involving the newly enacted fair dealing provision, and a few other novelties of that Act. This, perhaps, explains its enduring influence, despite the fact that it was a trial level decision. University of London might be an example of an easy case that makes bad law. The outcome of the case does not seem to be particularly controversial or revolutionary-not in retrospect, and probably also not at the time it was decided-but some of its dicta and misinterpretations of some of its holdings have turned it into an important milestone in the takeover of an owner-centric view of copyright in English law. $\cdot \frac{79}{}$

The defendants published a book entitled London Matriculation Directory, which contained several matriculation papers copied from a prior publication of the plaintiff, a subsidiary of the University of London, that were written by examiners hired by the university. The defendants' publication also included "answers to the questions in [some of] the papers...; and it also comprise[d] a short criticism of 
the construction of the various papers,... intended for the guidance of future examiners rather than for the edification of possible students." The court found that both publishers recognized that students and teachers derived significant utility from samples of previous examination questions, and that recognizing that demand, both publishers had decided to compete in that market. ${ }^{81}$ Even though the defendants' publication was not identical to the plaintiffs' and added its own content, copying a significant amount from one publication for the purpose of publishing a competing publication would hardly make an easy case for fair dealing, either today or a century ago. MacGillivray, who acted as co-counsel for the defendants, probably recognized that fair dealing would be an uphill battle, and focused most of its defense on other issues: whether the publisher plaintiff had any valid legal or equitable interest in the copied works, $\underline{\underline{82}}$ and whether the author co-plaintiffs suffered any damage. $\frac{83}{3} \mathrm{He}$ also challenged the copyrightability of the copied examination papers, arguing that the reference to "literary works" and "original" in the 1911 Act had set a higher standard compared to the 1842 Act, which referred only to "books". .44 Fair dealing was the last line of defense, pleaded in the alternative, should other arguments fail..$\underline{5}$

Peterson J's judgment appears to share the same view of the importance of the issues. It devoted only one paragraph to the fair dealing argument, which he easily dismissed without much elaboration. After describing how both publishers sought to compete in the same market, how there was very little in the defendants' work that could be seen as criticism, and how the partial answers provided by the defendant to some of the questions provided relatively little added value, he concluded that

It could not be contended that the mere republication of a copyright work was a "fair dealing" because it was intended for purposes of private study; nor, if an author produced a book of questions for the use of students, could another person with impunity republish the book with the answers to the questions. Neither case would, in my judgment, come within the description of "fair dealing." In the present case the paper on more advanced 
mathematics has been taken without any attempt at providing solutions for the questions, and the only way in which the defendants have dealt with this paper is by appropriating it, except that there are eleven lines of criticism of it, dividing the questions into easy, troublesome, and difficult questions. To the questions in the other two papers answers are provided. Both publications are intended for educational purposes and for the use of students, and in my judgment the defendants have failed to bring themselves within the protection of s. 2, sub-s. 1 (i.), of the Act..$\underline{6}$

When read in context, it is clear that University of London did not define what "private study" is, let alone hold that the term applied only to copying made by students for their own private use, nor it did say anything about whether fair dealing could apply to other purposes, beyond those explicitly mentioned in the Act. University of London stands only for the proposition that the mere republication of a work, by a competing publisher, without adding anything substantial, does not make a credible fair dealing case-a proposition that, on the reported facts of the case, does not seem to be highly controversial.

Nevertheless, for almost a century, this case has been misinterpreted, and was frequently cited as an authority supporting both propositions. The first misinterpreter seems to be F. E. Skone James, who, as the editor of the sixth edition of Copinger, cited University of London as authority for the proposition that private study "only covers the case of a student copying out a book for his own use, but not the circulation of copies among other students." $\underline{\text { " }}$ And until the Supreme Court's ruling in Alberta (Education), Canadian courts repeated this error.

For example, the Federal Court of Appeals (FCA) in $\mathrm{CCH}$ posited that "British courts have held that use in an educational institution was not for the purpose of private study", but despite the reference to "British courts" in plural, provided a single reference, University of London Press. ${ }^{88}$ The Court further added that "the Court in University of London Press, supra interpreted private study as not including educational purposes, and therefore did not allow professors to 
claim an exemption based upon their students' purposes."모 But University of London did not make any of those holdings. It did not deal with "professors [claiming] an exemption" or with "use in an education institution" but rather with two competing commercial publishers. Therefore, it did not and could not have held that "use in an educational institution was not for the purpose of private study". University of London held that the defendant publisher's dealing was not fair, but it did not interpret the meaning of "private study" at all, and nowhere did it mention professors invoking the private study of their students to justify their own copying and therefore could not have disallowed them to invoke it.

The Copyright Board in Alberta (Education) repeated the same errors. It stated: "Almost a century ago, British courts established a dichotomy between private study and teacher-student classroom interaction" and concluded that "[i]t therefore seems impossible that a copy made by a teacher for his or her class can be for the purpose of private study...".90 Like the FCA, it referred to "British courts" in plural while citing a single reference, University of London, and in a similar erroneous fashion suggested that University of London was a case about a classroom setting, when no discussion of "teacherstudent classroom interaction" exists there.

On appeal, the FCA endorsed the Copyright Board's interpretation. While the FCA did not repeat the same blatant errors, it still misinterpreted and misquoted University of London. The FCA recognized that "unlike the teachers in the case at bar, the University Tutorial Press was clearly using the examinations for commercial purposes", but concluded that this was an irrelevant distinction. The FCA explained that "Justice Peterson found this was not private study and therefore not fair dealing because the publications were "intended for educational purposes and for the use of students" as opposed to private study". 1 . This statement, however, misquotes and misinterprets University of London. The FCA quoted only half of a sentence, an omission that changes its meaning completely. The original sentence reads: "Both publications are intended for educational purposes and for the use of students, and in my judgment the defendants have failed to bring themselves within the protection of s. 2, sub-s. 1 (i.), of the Act." ${ }^{\prime 2}$ Clearly, Peterson J was not making any distinction between the 
defendant's "educational purposes and for the use of students" on the one hand and "private study" on the other, and he did not hold that fair dealing did not apply because the use had been for the former purpose and not the latter. Rather, he used the phrase "educational purposes and for the use of students" as a synonym to "private study" and was emphasizing that both parties' publications were intended for the same purposes, catering to the same market, and for that reason could not be considered fair dealing. The FCA confused a statement about the scope of fairness for a statement about the meaning of private study.

Ultimately, the Supreme Court declined to repeat these errors and noted that University of London had very little bearing on the meaning of "private study" and does "not stand for the proposition that 'research' and 'private study' are inconsistent with instructional purposes." $\underline{93}$

\section{British Oxygen}

British Oxygen $v$ Liquid Air ${ }^{94}$ involved two competitors: the plaintiff, who manufactured and sold oxygen gas, and the defendant, who manufactured equipment for producing oxygen gas. Both were competing for the same customers. To persuade a customer not to buy the defendant's equipment, the plaintiff offered that customer a deep discount conditional on a long-term exclusivity commitment. The details of the offer were communicated in a letter sent to the customer. The defendant obtained the letter from that customer, reproduced twelve copies, and sent one of them to a firm of stockbrokers on the London Stock Exchange, together with a letter complaining about the plaintiff's competitive tactics. $\frac{95}{}$ The plaintiff filed a lawsuit claiming copyright infringement.

The defendant challenged the copyrightability of such a letter, but argued that if such a letter was a literary work within the meaning of the 1911 Act, then its reproduction was permitted as fair dealing for the purpose of criticism. .6 The defendant also relied on earlier cases that found that a person was entitled to publish a letter when it was necessary to protect his character..$^{97}$ Romer J rejected all those 
arguments. He indicated that he was in agreement with the plaintiff's view that "criticism" within the meaning of the Act meant criticism of the work as such, but thought that he did not have to actually decide this matter because fair dealing simply could not apply to criticizing an unpublished literary work. Subjecting a literary work to public criticism, review or newspaper summary without the consent of the copyright owner would be, in his mind, "manifestly unfair."모 $\mathrm{He}$ further doubted that the right to publish a letter to vindicate one's character survived the passage of the 1911 Act and held that in any event that defence was inapplicable. .99

\section{Hawkes \& Son}

Hawkes \& Son involved the unauthorized use by Paramount Film of twenty seconds of the musical work Colonel Bogey (which lasted four minutes in total) in a newsreel reporting the opening of the Royal Hospital School by the Prince of Wales. ${ }^{100}$ At trial level, the defendants argued that the part copied was not substantial and that in any event fair dealing applied because "These news films are in effect a pictorial form of newspaper. The case comes within s. 2, sub-s. 1(i.), under which any fair dealing for the purposes of private study, research, criticism, review, or newspaper summary is not to constitute an infringement of copyright. The sound film is an audible and pictorial newspaper summary." 101 Eve J, the trial judge, ruled for the defendants on both counts. He held that in order to find for the plaintiff, he would have to find "that the introduction into the babel of sound inseparable from any pageantry, of a few bars of some more or less appropriate piece of music, would constitute an infringement calculated seriously to prejudice the rights of those whose aim is to reproduce the spectacle as a whole." 102 Such conclusion, he thought, was one that he could not believe could be right. ${ }^{103}$ He held that no substantial part of the work had been reproduced, and that if he was wrong about that then "the acts of the two defendants constitute a fair dealing with the work, under s. 2, sub-s. 1(i.), of the Act. [And that] it is impossible that what has been done can inflict any substantial injury on the plaintiffs' monopoly, or invade any market of the plaintiffs, actual or problematic." 104 
The Court of Appeals reversed. On appeal, the defendant's lawyers conceded that the part taken was substantial, but maintained that fair dealing applied, because

although it is admitted that the news reel cannot be called a newspaper summary it is something of much the same nature, and the matters specified in the proviso to s. 2, sub-s. 1, are merely examples of "fair dealing," and this case falls within the general principle involved in the proviso. The reproduction of part of "Colonel Bogey" was merely incidental to a sound film which as an item of news gave the opening of the Royal Hospital School by the Prince of Wales. $\frac{105}{}$

They emphasized that the reproduction was made for the sole purpose of indicating what happened when the Prince of Wales opened the school, and maintained, based on the case law prior to 1911, that the purpose of the reproduction had always been "of vital importance for the purpose of ascertaining whether there has been an infringement." 106 MacGillivary, who acted as co-counsel for the defendant, must have been familiar with the legislative history, and his argument that "the matters specified in the proviso to s. 2, sub-s. 1, are merely examples of 'fair dealing"' 107 is entirely consistent with that history. $\frac{108}{}$ However, his ability to rely on the legislative history was probably constrained, because even though it was trite that proper interpretation of a statute requires considering "how the law stood when the statute to be construed was passed, what the mischief was for which the old law did not provide, and the remedy provided by the statute to cure that mischief", 109 the use of extrinsic materials to help ascertain legislative intent was not permitted as it currently is. $\underline{110}$ Rather, the rule was that "Parliament's intention must be gathered solely from the Act itself". 111

The case is also interesting because it foreshadows some of the problems of overlaying royalties that would occupy the Supreme Court of Canada in 2012. The defendants emphasized that the "march has been performed in 417 cinema theatres with the consent of the author of the composition and on payment of fees to the plaintiffs. The only question is whether the making of the film is 
unauthorized." 112 They must have referred to a blanket licence issued by the Performing Rights Society, but they did not and could not get a timely synchronization licence if one was needed, and urged that a holding for the plaintiff under the circumstances would seriously hamper trade. Lord Hanworth M.R. dismissed the argument, noting that the plaintiffs "do not at all intend or desire to hamper trade. All that they say is this: that if this reproduction of a copyright musical march is allowed or is sought by the defendants, then, on a payment, that licence can be granted." 113 He dismissed the defendants' argument that "the rapidity with which they have to reproduce these new films makes it difficult, or indeed impossible, for them to obtain a licence from the owners of the musical copyright. Some system could no doubt be arranged whereby, if there is a possibility of some infringement of copyright, there could be a licence applicable to the occasion, so as to avoid any damage to the plaintiffs or other owners of copyright." 114 By "some system" he might have thought about obtaining an additional licence from a collecting society (a solution that would probably be viewed as undesirable "double dipping" by the Supreme Court of Canada, post ESA $v$ SOCAN), $\frac{115}{\underline{1}}$ but he did not elaborate. $\frac{116}{}$

Lord Hanworth then turned "simply to look at the statute" and to interpret it according to its purpose, which in his view was "the necessity for the protection of authors whether of musical or of literary compositions." 117 In interpreting the Act as if that was its only purpose, he adopted a very strong owner-centric view of copyright, ignored its public interest goals, and dismissed the relevance of any consideration of whether the defendant's actions caused any harm to the plaintiff.. 118 Turning to consider the fair dealing argument, he rejected the defendant's argument that the film was analogous to a newspaper summary. In an extremely narrow interpretation of the statute, he held that "the collocation of the words 'criticism, review, or newspaper summary' clearly points to the review or to notices of books which appear in newspapers, and not to anything of the nature that was done in the present case." 119 This holding was a clear departure from pre-1911 case law, which did not limit "review" to those narrow settings,, 20 and recognized that "criticism" did not apply solely to criticism of the copied work, but could extend to criticizing the views contained in it. $\underline{121}$ 
Slesser LJ agreed with Lord Hanworth and added a few interesting remarks. While he acknowledged that the notion of "substantial part" appeared in the statute for the first time in 1911, he emphasized the continuity with the pre-1911 case law and the fact that Parliament explicitly codified what had already been decided by the courts under the previous legislation. $\frac{122}{2}$ Interestingly, however, when considering the defense of fair dealing, he declined to recognize any similar continuity with the previous case law and adhered to strict and literal interpretation of section 2(1)(i). He took the view that "this proviso must be dealt with strictly, and when it says 'newspaper summary' it means newspaper summary and nothing else. Now here there is neither a summary nor a newspaper, and it is impossible, I think, to hold that this case comes within that protection." 123

Romer J, despite showing some sympathy to the defendants, who caused no harm to the plaintiffs, was equally dismissive of their legal arguments. He joined the view that the plaintiffs' harm-or lack thereof-was irrelevant because the plaintiffs were simply asking the court the enforce their property rights, $\frac{124}{2}$ and reasoned that even if the defendants' film could be analogized to a newspaper summary, it was nonetheless unfair, because a newspaper reporting on the Prince of Wales's visit would be free to report that the schoolboys marched past him to the tune of "Colonel Bogey" but it could not reproduce a substantial part of the tune's musical score for the benefit of readers who were not there. $\frac{125}{2}$ This reasoning, of course, misses the point entirely. Not only does it assume that benefiting the readers who were not present is an irrelevant consideration, what it considers as a legitimate form of news reporting that might benefit from the fair dealing provision does not involve any reproduction of any part of the work at all.

The strong proprietary and owner-centric language used by the judges makes it difficult to speculate whether the outcome of Hawkes \& Son would have been different under an explicitly openended fair dealing provision, or one that used a different term from "newspaper summary." In any event, while the owner-centric legacy of Hawkes \& Son continued to burden Commonwealth law for many years, some of its harsh consequences were relieved through legislative change. In 1956, the UK changed the term "newspaper 
summary" to "reporting current events"126; Canada would do the same in 1997, by replacing "newspaper summary" with "news reporting". 127 Subsequent amendments in both countries also exempted "incidental inclusion".

It appears that this view of fair dealing as limited to the explicitly enumerated purposes has never been challenged, and accordingly courts did not have the opportunity to thoroughly consider it. Nevertheless, suggesting that prior to $\mathrm{CCH}$, all Commonwealth courts subscribed orthodoxically to Hawkes \& Son's overly restrictive view of fair dealing would be an error. On occasion, courts have approached fair dealing in a more liberal way. For example, in Hubbard $v$ Vosper, Lord Denning declined to interpret fair dealing as narrowly as the plaintiff suggested, and did not follow British Oxygen's suggestion that "criticism" was limited to "criticism of the work as such" or that fair dealing cannot apply to criticizing unpublished works. $\stackrel{129}{ }$ Moreover, his canonical statement that "It is impossible to define what is 'fair dealing"', the general test that he offered for applying it, and his observation that "[a]s with fair comment in the law of libel, so with fair dealing in the law of copyright. The tribunal of fact must decide" 130 reflect a vision of flexibility and common law adjudication rather than one that sees courts as strictly bound by the literal confines of the statutory provision. A year later, the holding in Hubbard $v$ Vosper led the court to recognize that a common law "public interest" defence may "override the rights of the individual, (including copyright), which would otherwise prevail and which the law is also concerned to protect." $\underline{131}$

Pro Sieben $v$ Carlton is also noteworthy for its suggestion that the phrase "for the purpose of" ought to be interpreted as "in the context of" or "as part of an exercise in"-an interpretation that defies strict construction of each of the individual purposes, and prefer an application of fair dealing in a wider array of circumstances. ${ }^{132}$ In Allen $v$ Toronto Star, the court concluded that since "the nature and purpose of the use by the Toronto Star...of the [plaintiff's] photograph [was] to illustrate a current news story, the defence of fair dealing applie[d] in the circumstances of this case." 133 Even though the use might not fall neatly within the "newspaper summary" rubric, the court did not feel itself strictly bound by that. Guided by Lord Denning's general 
test for applying fair dealing, the court reasoned that "test of fair dealing is essentially purposive. It is not simply a mechanical test of measurement of the extent of copying involved". 134

\section{IV: Interpreting the 1911 Act}

The crucial question, therefore, is what the UK Parliament was trying to achieve and what it thought it was doing when it enacted the fair dealing provision in 1911. Did Parliament intend to replace the common law doctrine with an exhaustive statutory regime but without changing its scope, or did it contemplate a limited statutory regime that coexists with the common law? Did Parliament intend to amend the common law of fair use or fair dealing by confining the doctrine to the five enumerated purposes and restrain the judiciary from further developing it on a case-by-case basis, in light of new circumstances and new types of uses, or was Parliament's intention merely to clarify that the doctrine existed without restraining courts' power to continue developing it? Might it even be possible that in addition to clarifying the existence of the doctrine, Parliament intended to expand it? While plain reading of the statutory language may support the interpretation that Parliament replaced and restricted the common law doctrine, other principles of statutory interpretation, including the legislative history, support the conclusion that that is the least likely interpretation.

This part begins with discussing the restrictive interpretation, largely based on the fair dealing provision's plain meaning, and then proceeds to refuting it.

\section{A. Interpreting the text}

\section{Expressio unius}

The strongest support for the interpretation that section 2(1)(i) of the 1911 Act (and its subsequent iterations in the Canadian legislation) confines fair dealing to the five enumerated purposes and excludes all other purposes is implied exclusion, based on an inference from the Act's language. Arguably, if Parliament intended to allow courts to 
apply fair dealing to other purposes beyond the enumerated ones, it would have said so. Parliament could have added the words "such as" (as the US Congress did in 1976) or could have used similar drafting techniques to clarify that the enumerated purposes are illustrative rather than exhaustive. In other words, expressio unius est exclusio alterius: "to express or include one thing implies the exclusion of the other." 135

While expressio unius is helpful in determining a text's linguistic meaning, it does not necessarily ascertain its legal meaning. $\frac{136}{}$ As Barak writes,

logic governs the scope of this canon [of interpretation]. If I say that people are mortal, you should not infer that animals live forever. Even when it is possible to infer "no" from "yes", that choice does not necessarily become the text's legal meaning. Perhaps the "yes" itself is included merely as a precaution, to remove doubt (ex abundanti cautela); perhaps it is only an example; perhaps it reflects sloppy writing. $\frac{137}{}$

Therefore, "[l]ike the other presumptions relied on in textual analysis, implied exclusion is merely a presumption and can be rebutted." 138

As the proceeding analysis shows, this presumption can be easily rebutted in the present context. There is no evidence in the legislative history to support the expressio unius interpretation, and there is sufficient evidence supporting the proposition that the most likely interpretation of the meaning of the "yes" is that rather than implying "no", it reflects Barak's three possibilities: some of the purposes may have been included to remove doubt; all of them, read together, stand in synecdochically for a variety of permissible uses; $\frac{139}{}$ and, admittedly, and in retrospect, the omission of "such as" reflects sloppy writing.

\section{A Note on Plain Meaning}

Even though the expressio unius interpretation assumes that the statute's meaning is clear, it must be noted that this clear meaning is nevertheless peculiar. The notion that fair dealing applies only to certain allowable purposes implies that "[d] ealings for other purposes are not covered by the exception, even if they would otherwise be 
fair". ${ }^{140}$ This means that when the UK Parliament enacted in 1911 (and Canada's Parliament enacted in 1921) that "Any fair dealing with any work for the purposes of private study, research, criticism, review, or newspaper summary...shall not constitute an infringement of copyright", it meant that dealings with works for other purposes, even though they may otherwise qualify as fair, still constitute an infringement of copyright.

Under this interpretation, the scope of permissible copying is limited twice: first, by selecting only five categories of uses that could be eligible for an exemption, and then further narrowing them down by allowing only those among them that would be found to be "fair". Even though this interpretation is plausible grammatically, it is paradoxical logically, because it implies that even though some activities might be entirely fair, they would still be categorically unlawful. But the adjective "fair" usually stands for something that is "just or appropriate under the circumstances", $\underline{141}$ and it would seem rather peculiar to adopt a provision that recognizes that some dealings are just or appropriate, but are still unlawful. If the intent had really been to limit the exception only to the five enumerated purposes, and further limit it to the subset of those that are fair, it would have been open to say "it shall not constitute an infringement of copyright to deal with any work for the sole purposes of private study, research, criticism, review, or newspaper summary, and provided that any such dealing is fair."

This point provides an additional illustration to the perils of plain meaning interpretation. Legislated texts are imperfect, and sometimes their legal meaning cannot be based solely on their textual meaning, but should be aided by resort to the legislative history and other interpretative principles, which are discussed below.

\section{3. "Research" and "Private Study"}

A hurried plain meaning approach has also resulted in a restrictive interpretation of the term "private study". Since the meanings of "research" and "study" overlap considerably, the fact that the adjective "private" precedes "study" but not "research" has led some to interpret this difference as an indication that Parliament intended "to expressly qualify 'study' but not 'research' [which] indicates an intention to 
permit all fair research, whether in a private setting or not" $\underline{142}$ but disallow study that is "non-private". view was adopted by the decisions below, as well as by Rothstein $\mathrm{J}$ in his dissenting opinion at the Supreme Court. According to him, "Parliament does not speak in vain" 144 and the only possible interpretation that would respect Parliament's intention would be to interpret "private study" as excluding other forms of "non-private" study, which means that "private study" means "study by oneself", and excludes copying done by teachers to support their students' private study in the ordinary course of instruction. $\underline{\underline{145}}$

While there is no question that this interpretation is within the range of plausible linguistic meanings, it is certainly not the only one, nor is it the only one consistent with the presumption that Parliament does not speak in vain. While Rothstein J conceded that the word "private" does not necessarily limit "study" to studying in solitude, $\underline{146}$ he failed to recognize the existence of a wider spectrum of meanings. A standard lexical meaning of "private" is "not open to the public", $\underline{147}$ and distinction between the legal significance of acts that are public and those that are not runs throughout the Act and copyright doctrine. $\frac{148}{\underline{4}}$ Applied to "private study", this meaning could comfortably include study that is done in a setting that is not open to the public at large, such as in the case of ordinary classroom instruction.

In fact, rather than interpreting "private study" and "instruction" as antonyms, as Rothstein J and the decisions below did, English courts, before and after the enactment of the 1911 Act, interpreted "private study", "teaching", and "instruction" as synonyms. The distinction that was made was not between "private study" and "teaching", but between works that are communicated to others in private settings and those communicated to the public at large.

For example, in Caird $v$ Sime, $\underline{149}$ decided in 1887, the House of Lords held that a university professor had not forfeited his power to prevent the first publication of his lectures by delivering them to his students in the classroom in the ordinary course. Such lectures were held not to be public in the sense of being "communicated urbi et orbi by the mere act of delivery", 150 but private "inasmuch as the author does not by their delivery communicate his ideas and language to the public at large." 151 The Lords reasoned that the professor's duty as a 
teacher was not to address the public at large, but "to give personal instruction to the individuals composing his audience."152 "The relation of the professor to his students is simply that of teacher and pupil; his duty is, not to address the public at large, but to instruct his students." 153 This sentence could easily read "the teacher's duty is to assist students in their private study, not to address the public at large" without altering its meaning or the rationale of the ruling. $\frac{154}{}$ Printing and selling copies would amount to publication, but "giving copies for private perusal or by recitation before a select audience... admitted for the purpose of receiving instruction or amusement" $\underline{155}$ would not. $\frac{156}{}$

This interpretation opens the possibility that the term "private study" was not inserted to prevent fair dealing from applying to teaching, but instead to make sure that it does. As I explain in greater detail below, the case law on fair use prior to 1911 dealt predominantly with defendants who published works incorporating parts of, or based on, works of others. Where courts found that the use was fair, it was usually because the parts that were copied were non-copyrightable, not substantial, or that the defendant's work had been-in modern terms- "transformative." The few cases involving "private use" in the sense of "not public" were actually held to be infringing. Therefore, prior case law might have been interpreted as allowing only transformative uses that enrich the public by adding to the stock of knowledge, and excluding non-transformative or non-public uses (or both). $\frac{157}{}$ On this account, "private study" could have been added to pre-empt such restrictive interpretation. Thus, by adding "private study" in addition to "research", Parliament did not speak in vain at all, although it meant something different from what Rothstein J understood. $\underline{158}$

\section{B. Legislative History of the 1911 Act}

"The legislative evolution and history of a provision may often be important parts of the context to be examined as part of the modern approach to statutory interpretation." 159 Understanding the meaning of fair dealing also requires understanding the law that existed prior to 1911 and what changes, if any, the 1911 Act intended to effect. $\frac{160}{}$ 


\section{Background: The Law Prior to 1911}

The Copyright Act, 1911 was "An Act to amend and consolidate the Law relating to Copyright." As early as 1878 , consolidation of the law was recommended by a Royal Commission, which found the existing law "wholly destitute of any sort of arrangement, incomplete, often obscure, and, even when intelligible upon long study, so illexpressed that no one who did not give such study to it could expect to understand it." 161 As MacGillvray noted, "The great obstacle in the way of consolidation and amendment has been the difficulty in coming to a satisfactory settlement with the self-governing dominions. Canada, in particular ...”.162 Indeed, Canada was concerned about the prohibitively high prices of British publications, which "were beyond the means of the ordinary reading public in Canada." 163 Some additional amendments were required in order to comply with the first revision of the Berne Convention for the Protection of Literary and Artistic Works signed in 1908. $\frac{164}{}$

In addition to extending the term of copyright protection, its application to new subject matter and the abolition of mandatory registration, the new Act broadened the definition of what copyright was, expanded the definition of what constituted infringement, and enlarged the scope of remedies that might be available to the plaintiff under the Act, in comparison to what was contained in the Copyright Act, 1842. The changes were not entirely revolutionary, because many of them reflected developments already recognized in the case law. Still, their explicit recognition in the new statute removed any doubt that the rights and remedies were broader than those explicitly stated in the 1842 Act. For example, section 2 of the 1842 Act provided that 'the word 'copyright' shall be construed to mean the sole and exclusive Liberty of printing or otherwise multiplying Copies of any Subject to which the said Word is herein applied"; $\frac{165}{}$ section 1(2) of the 1911 Act made it clear that the exclusive right was not limited to reproducing the entire work, but extended to a reproduction of "any substantial part thereof". It also clarified that the exclusive right to reproduce was not limited to reproduction in the same material form (e.g., a printed book reproduced into another book), but also included reproductions 
"in any material form whatever", including additional techniques, such as lithography. $\frac{166}{}$

Even more significant change was eliminating what appeared to be a mismatch between the scope of the exclusive right under section 2 of the 1842 Act and the definition of what constituted infringement under section 15. While section 2 defined "copyright" as "the sole and exclusive Liberty of printing or otherwise multiplying Copies", 167 remedy appeared to have been available only to a narrower set of commercial activities $\frac{168}{}$ (similar to those currently termed "secondary infringement" in section 27(2)). $\frac{169}{}$ Thus, the 1842 Act made actionable not the mere act of unauthorized reproduction, but only commercial dealing with such unauthorized reproductions, such as distribution, importation or exportation. This might have meant, and perhaps indeed meant, that reproductions outside this commercial domain were simply beyond the scope of the Act and not actionable. These could include, for example, copies made by individuals for their own personal use, but also copies made by teachers for educational purposes, and indeed any copying, as long as the copies were not commercially dealt with in the ways described in section 15 .

Since entirely almost all reported cases, including those where copying was found to be fair use, involved commercial dealings (e.g., a published book containing extracts from another), it is hard to tell whether the lack of cases dealing with non-commercial copying reflected a common understanding that those types of reproductions were not prohibited by the Copyright Act, or whether the lack of cheap and ubiquitous reproduction technologies meant that instances of such non-commercial copying were rare, or at least did not really trouble copyright owners. In other words, it is hard to tell whether the mismatch between the right and the remedy under the 1842 Act was intentional or an oversight.

However, in the first case whose outcome would turn on the answer to this question, the court decided that Parliament could not have intended to render actionable only commercial activities. This case, Novello $v$ Sudlow, $\underline{170}$ involved 250 lithographic reproductions of a musical work (in the form of a music sheet) that were made and distributed to members of The Liverpool Philharmonic Society, to be performed in a particular event. This society, "consisting of several 
hundred persons, was established for the purpose of giving concerts and musical performances for the gratification of the members, and for the promotion of music, and not as a source of profit to the members, who performed gratuitously." $\underline{171}$ The court struggled with the argument that section 15 of the 1842 Act rendered gratuitous distribution of these copies non-actionable, but eventually ruled that Parliament could not have intended to limit the common law remedies available to a granted property right and ruled for the plaintiff. $\frac{172}{}$

But this case was not a House of Lords case, so it might not have provided the certainty that copyright owners would have desired. The 1911 Act, however, removed any doubt about that. Unlike the 1842 Act, the definition of an infringement in section 2 of the 1911 Act applied explicitly to "any person who, without the consent of the owner of the copyright, does anything the sole right to do which is by this Act conferred on the owner of the copyright". In addition, to remove any doubt about the scope of available remedies, section 6(1) explicitly provided that "Where copyright in any work has been infringed, the owner of the copyright shall, except as otherwise provided by this Act, be entitled to all such remedies by way of injunction or interdict, damages, accounts, and otherwise, as are or may be conferred by law for the infringement of a right." 173

This overview helps understanding the motivation for legislating a fair dealing provision-what hitherto had been a set of loosely defined common law rules and principles.

A simple explanation might be that since the 1911 Act was mainly a project of consolidation of different acts and codification of different common law rules, it seemed prudent not to leave fair use without any statutory basis. Even though the Royal Commission in 1878 recommended against legislating fair use, noting that "In the majority of cases these are questions that can only be decided, when they arise, by the proper legal tribunals, and no principle which we can lay down, or which could be defined by the Legislature, could govern all cases that occur", 174 it is possible that the drafters of the 1911 Act had a different view and thought that their ambitious project of codification and consolidation would be incomplete without mentioning the doctrine in the statute. ${ }^{175}$ 
Another explanation relates directly to the changes described in the previous paragraphs. Possibly, if the Act recognized only the expansion of the copyright but remained silent about limitations to those expanded rights, courts might have interpreted that as a signal that Parliament had decided to abolish fair use. MacGillivray, in his 1912 commentary, offered an explanation along those lines:

The protection granted under the general definition of copyright in sect. 1 is so absolutely prohibitive of any use in the nature of a reproduction of the whole or any part of the author's work, that it is necessary to introduce the exceptions specified in sub-section (i) [of s 2]. It would hardly have been safe to have left it entirely to the Court to say what exceptions should or should not be admitted upon the analogy of the case law decided under the Copyright Act, 1842. 176

Of course, Parliament could have achieved this result by simply stating that "any fair dealing with any work does not constitute copyright", without specifying particular purpose. This, however, might have been considered too vague, and it would make sense to give some illustration.

Alternatively, it is possible that the purpose of specifying the five categories was not only to remove any doubts that fair dealing applied to those already recognized in the case law, but also to ensure that it applied to those who lacked solid grounding in the case law. In particular, the addition of "research", "newspaper summary" and "private study", categories that had no direct precedent in the case law, can support this explanation. Although commentators such as MacGillivray noted that "The liberty of fair dealing by way of research [was] probably intended to express the whole of the existing case law on the meaning of fair use", 177 there does not seem to be prior case law dealing with research as such, possibly because reproduction for the purpose of research that did not involve publication or distribution was not a reason for concern and might not have even been actionable

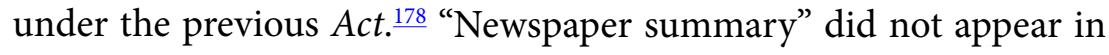
the Bill, but was added in Committee. $\frac{179}{}$ And "private study" might have been added to overrule, or at least narrow the scope of, the holding in Novello $v$ Sudlow and its progeny. $\frac{180}{}$ 
Lastly, and in contrast, it is possible that by specifying five classes of cases to which fair dealing applies, Parliament intended to modify the common law, limit fair dealing to those and only those categories, and prevent the courts from recognizing additional ones. However, despite the fact that this view has been accepted lately as conventional wisdom, it is the least likely of all explanations. As we shall see below, there is no evidence supporting this explanation, and sufficient evidence to reject it.

\section{The Legislative Record}

Unfortunately, the legislative record is not rich enough to determine precisely and unequivocally what was Parliament's intent in 1911, but it contains enough to refute the claim that the codification of fair dealing was intended to confine it to the five enumerated purposes, or otherwise change the common law nature of the doctrine. The record contains sufficient evidence to the contrary, and it also demonstrates the difficulties in drafting a detailed provision to codify a principle that defies precise articulation.

When the Bill was introduced to the House of Commons, Mr. Buxton, the President of the Board of Trade (the ministry responsible for drafting the legislation), surveyed the main changes in the proposed Act. $\frac{181}{}$ If the Bill contemplated major reform with respect to fair dealing, it would have been expected that such change was mentioned, but it was not. Nor did Viscount Haldane, who introduced the Bill to the Lords, mention any contemplated change with respect to fair dealing. In fact, in objecting to a motion "to confine to literary and dramatic works the doctrine of fair dealing which has been laid down by the Courts, and not to

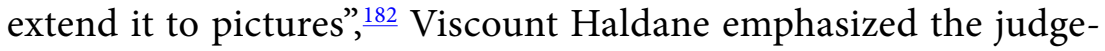
made nature of the doctrine of fair dealing and stated:

All we propose to do is to declare that for the future the principle of fair dealing which the Courts have established is to be the law of the Code. ... The principle of fair dealing is a principle which the Courts have applied with the greatest care. ... All that is done here is 
to make a plain declaration of what the law is and to put all copyright works under the same wording. $\frac{183}{}$

This statement proves illuminating in several respects. First, it regards fair dealing as a principle, and recognizes that the purpose was to codify a general principle, applicable to a wide range of circumstances, instead of legislating specific rules, articulating specific exceptions, tailored to specific circumstances. Second, it clarifies that there was no motivation to effect any change in the nature of that principle, only to declare its existence. Third, it shows that there was no concern that the application of this principle by the courts had caused any mischief, and that legislation was required to rein them in and limit their discretion. Instead, the statement evinces trust in the way courts have applied the principle and confidence in their continued ability to do the same in the future.

The parliamentary debates provide additional evidence. One of the debates concerned the status of copyright in written letters. One Member of Parliament proposed adding to section 2 an explicit exception permitting "The publication of letters where such publication is necessary in the public interest, or to preserve or establish the rights or reputation of the recipient or his family" 184 It was argued that the new Bill would take away such a right, which the courts had previously recognized. $\frac{185}{}$ The Solicitor General opposed the amendment on the basis that such an amendment was unnecessary, because courts are perfectly capable of dealing with these issues, should they arise. He described the law as it stood then in the following way:

A man who receives a private letter from another must not make an unconscionable or unfair use of it-he must not sell copies of it for reward or exercise a copyright in it. That would be to make an unfair use of it. But it may be possible that there are cases when a man who has received a letter, although he has no copyright in it, may be entitled to produce it in a court of law and publish it.

He argued that there was no need for an explicit exception because the courts can be trusted not to enjoin or award damages against a person who published a letter when the publication was justified. 
He believed that leaving that for the courts to decide is a better approach than creating an explicit exception that might be abused. $\frac{186}{}$ The subsequent withdrawal of the proposed amendment confirms that Parliament did not consider section 2 as preventing courts from finding certain uses to be fair, even if not mentioned explicitly. $\frac{187}{}$

Recent scholarship by Robert Burrell and Allison Coleman $\frac{188}{}$ and from Isabella Alexander $\frac{189}{10}$ provides further evidence. ${ }^{190}$ It appears, therefore, that section 2(1)(i) was meant to codify the principle of fair dealing, without restricting or limiting its application, adaptation and adjustment by the courts according to the circumstances of particular cases. By specifying instances of dealings (two of which-criticism and review-were well recognized by the courts, and three-private study, research and newspaper summary-were new) and subjecting them to an overarching principle of fair dealing, Parliament intended to guarantee the continued vitality of the doctrine. As Isabella Alexander writes, rather than to restrict, the five enumerated purposes "were intended to be understood synecdochically as standing in for a variety of permissible uses." $\underline{191}$

\section{Additional Extrinsic Evidence}

In addition to the legislative record, other contemporaneous extrinsic aids support the view that the 1911 Act was not meant to restrict fair dealing and confine it to the five enumerated purposes. Several commentaries followed the enactment of the 1911 Act. All of them offer a general overview of the 1911 Act and survey the motivations for enacting it and the main changes relative to earlier law. Neither of them mentions fair dealing in that context, let alone viewing the fair dealing provision as a major change compared to previous law, nor do they indicate that the previous law on fair use was deficient in its overbreadth. All of them, when discussing the various provisions of the $1911 \mathrm{Act}$, including the issue of infringement, refer to earlier case law, thus clearly indicating that they did not regard the 1911 Act as revolution, but as evolution of a previous body of statutory rules and common law interpretation.

The views expressed in two of the leading contemporaneous commentaries on the 1911 Act are particularly noteworthy. 
MacGillivray, as noted earlier, suggested that the fair dealing provision was added out of abundance of caution. ${ }^{192}$

J. M. Easton, the author of the fourth and fifth editions of Copinger on Copyright, the leading treatise on copyright,, 93 noted that "[a]ny fair dealing, with, any work for the purposes of private study, research, criticism, review, or newspaper summary is also expressly permitted by the Act", but wondered why it was even necessary to include an explicit fair dealing provision for the enumerated purposes, because "fair dealing for other purposes has always been...permitted and, presumably, it was not intended to cut down the rights of fair use previously enjoyed under the old law." 194

Richardson's general observation about the 1911 Act is consistent with Easton's. In his introduction, he remarked that

The passing of The Copyright Act, 1911, has completely recast the Law of Copyright, at any rate those parts which depend primarily on Statute Law, such as the term of protection and ownership of copyright. Only those parts of the law which are practically judge-made-such as the questions as to infringement by a new work other than an exact copy-have remained to any great extent unaltered, and even they are not untouched. .195

L. C. F. Oldfield's commentary did not seem to read section 2(1) (i) as limiting the common law of fair use either. In his introduction, he stated that when an Act of Parliament has received judicial construction, and a later Act in pari materia uses the same words, it is presumed that those words retain their meaning, unless there is indication to the contrary. ${ }^{196}$ His discussion of fair dealing reveals that he did not see anything in the 1911 Act suggesting alteration of the law on fair use. After repeating the statutory provision, he explained that "[w]hat is fair dealing with a work depends upon the circumstances of each particular case", and quoted a paragraph from an American case, which he regarded as giving "an excellent summary of the law". 197

Oldfield then turned to discussing the question of abridgements, and concluded that "[i]t is submitted that the present Act does not alter the law with respect to abridgements, and that if bona fide and original, although made without the original author's consent, they 
are not infringements." 198 Earlier in the book, he even noted that the Copyright Bill, as introduced, contained an explicit exception for making an abridgement for private use, but "under the present Act there is no specific mention of abridgements, but any fair dealing with a work for the purpose of private study or research is not an infringement" and concluded that as a result "under this Act, the author of an original work cannot prevent the publication of any fair and bona fide abridgement which in its nature is original..."199 The fact that abridgement was not mentioned in section 2(1)(i) did not bother him.

G. S. Robertson's commentary ${ }^{200}$ discusses fair dealing rather briefly, noting that " $\mathrm{t}]$ his exception is couched in very wide terms, and its limits are not easy to define" 201 and then contains some inconsistent statements. At one point he explained that "the proviso which permits fair dealing for [the enumerated] purposes...covers the cases, which have caused some difficulty in the minds of judges, where a reproduction of an artistic work is made by hand for the purpose of private study or amusement." $\stackrel{202}{ } \mathrm{He}$ then stated that "the reproduction, however, when made, must not be dealt with for any other purpose than one of those specified in the proviso." 203 It can be immediately noticed that "amusement", which he claims to be covered by the proviso, is actually not specified in it. $\frac{204}{}$

In sum, if by enacting the fair dealing provision Parliament had intended to modify the existing doctrine of fair use by confining it to five enumerated categories exclusively, most of the contemporaneous commentators failed to notice that intention. The parliamentary debates do not support this view either. In Canada, the debates in 1921 do not contain any meaningful discussion of fair dealing.

The view that Parliament had intended to restrict fair dealing to the five enumerated purposes began appearing later. In 1927, the sixth edition of Copinger was published. This edition was no longer authored by Easton, but penned by F. E. Skone James and published by a different publisher. The sixth edition's view about the scope of fair dealing was entirely different and considerably more restrictive. In Skone James's view, the principle embodied in section 2(1)(i) limited "the right to fair use to purposes which in their nature are likely to differ from those of the works from which extracts are taken". He 
clearly regarded the enumeration of the five purposes as a "limitation of purposes in regard to which the defence of fair dealing can be set up", a limitation that "has probably not altered the law, but it has prevented any attempt to extend the defence to new purposes." 205 Skone James provided no authority to support this restrictive interpretation and, remarkably, failed to acknowledge that a contrary view was expressed in the previous edition of the same book. Instead of grappling with the contrary position, he simply chose to omit it.

Skone James's treatment of the meaning of "private study" was equally deficient. While Easton, in the fifth edition, took the view that section 2(1)(i) narrowed the scope of the holding in Novello $v$ Sudlow ("It is no defence that the copying is made for the purpose of gratuitous circulation, unless it be for private study or research") 206 - a position that would include circulation to students-Skone James took the opposite view, asserting that '“[p]rivate study', it is submitted, only covers the case of a student copying out a book for his own use, but not the circulation of copies among other students." $\stackrel{207}{\text { Again, Skone }}$ James failed to acknowledge the reversal from the position stated in the previous edition, and purported to support this proposition by reference to University of London Press, a case that, as discussed above, had nothing to do with gratuitous circulation among students.

Perhaps it was the status of Copinger as the leading treatise on copyright that entrenched the restrictive view of fair dealing, despite the fact that this view has misstated the meaning of the 1911 Act.

A Canadian leading treatise has witnessed a similar inexplicable reversal of view on fair dealing, from one observing continuity with the pre-1911 case law to another emphasizing disjuncture. Writing in 1944, Harold Fox, in his first treatise on Canadian copyright law, took it for granted that a statutory fair dealing coexisted with a common law fair use. ${ }^{208}$ In numerous other places, he referred to fair use, relying indiscriminately on prior English and American cases. $\frac{209}{}$ Nowhere did he suggest that the UK 1911 Act or the Canadian 1921 Act rendered the common law concepts of fair use obsolete, and nowhere did he suggest that by enacting the fair dealing provision, Parliament adopted a fundamentally different and more restrictive view of what constitutes infringement compared to American law. Apparently, his view was that the statutory fair dealing allowed only 
the enumerated purposes, and that " $[\mathrm{t}]$ hose terms will no doubt

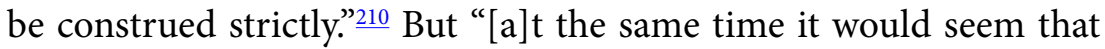
'substantiality' of the amount copied is still a test for infringement and that the Court still has jurisdiction notwithstanding section 17(1)(i) [the fair dealing provision] to hold that a substantial part of the work has not been taken where the part or parts taken can be justified as fair use or fair quotation." 211 Thus, the statutory fair dealing would apply even when substantial part was taken, $\underline{212}$ and "affords additional protection to defendants", that is, even beyond what might be permitted as fair use. $\stackrel{213}{ }$ While his view of what the common law of fair use had permitted might be overly restrictive, the crucial point is that he viewed the statutory right as expanding upon it. Fox's second edition from 1967 repeats the same view. $\underline{214}$

Fox died in 1969; the third edition of his treatise, by John McKeown, was published in 2000. $\frac{215}{}$ The discussion in the previous editions of the pre-1911 case law on fair use has all but disappeared. When discussing what constitutes infringement, McKeown stated:

Prior to the British Act of 1911, a number of cases took the approach that it was not an infringement for a compiler to refer to a preceding work or works and take extracts from them so long as the author expended skill and labour which resulted in the production of a new original work and the alterations made were not of a merely colourable character. This was referred to as "fair use" of an earlier work. In light of subsequent cases and the current provisions of the Act this approach is no longer appropriate. $\underline{\underline{216}}$

McKeown did not refer to any specific subsequent cases or any current provision of the Act that he relied on. Moreover, he failed to acknowledge Fox's much richer account of fair use and his different view of the relevance of pre-1911 cases. Rather than explaining why Fox's view might have been incorrect when it was written, or at least was no longer correct, he simply ignored it.

While Fox's discussion of the concept of "lawful use" began with restatement of the general common law concept of fair use before turning to the statutory fair dealing, McKeown's editions address 
only the statutory fair dealing. Again, the change of heart was neither acknowledged nor defended. The only hint to the possibility that other exceptions might apply was an assertion, in reference to Bishop $v$ Stevens, that "[s]ince copyright law in Canada is purely statutory law an implied exception from infringement seems unlikely."217 To the extent that this view was defensible in 2000, it ought to be questioned in light of the recent Supreme Court decisions and of the Court's explicit repudiation of the vision of copyright that informed its holding in Bishop. .18

In any event, most recent and present discussions about copyright and about copyright reform in Commonwealth jurisdictions have taken it for granted that fair dealing cannot apply beyond the explicitly enumerated purposes. This assumption was shared both by those who advocated replacing the current fair dealing regime with a nonexhaustive provision as well as by their opponents. Proposals to amend the Act in this direction never came to fruition, $\frac{219}{19}$ and the preferred approach in all recent rounds of copyright reform-or maybe, more accurately, the political compromise-was to specify additional exceptions instead. $\frac{220}{2}$ Does that indicate Parliament's intent to have a closed fair dealing regime? The answer is no. It would be tempting to say that Parliament did not adopt those proposals for reform because it correctly recognized that the existing provisions were never intended to be exhaustive and reform was unnecessary. But this would be inaccurate. The truth is that while Parliament recognized needs to expand exceptions, it chose not to open up the fair dealing provision but chose a different path. But even if this choice reflects the way that recent Parliaments interpreted the existing provision, this perception does not change the meaning of the original provisions. Parliament enacts laws, but it does not interpret them.

\section{Additional Principles of Statutory Interpretation}

\section{The Mischief Rule}

The mischief rule, traced back to the Heydon's Case of 1584, instructs courts to discern and consider the following: (1) what was the common law prior to the enactment of the statute; (2) what was the mischief and defect for which the common law did not provide; 
(3) the remedy that Parliament proscribed for that mischief; and (4) "The true reason of the remedy; and then the office of all the judges is always to make such construction as shall supress the mischief, and advance the remedy." 222

Since fair dealing had no statutory basis prior to 1911 and there was no case law holding that the doctrine can apply only to the five enumerated purposes, it must be the case that courts prior to 1911 could expand fair dealing to new purposes that had not been recognized before. Therefore, the view that the 1911 Act has limited the power of courts to apply the doctrine to additional purposes must suppose that Parliament had had such intention. As the previous discussion makes clear, there is no indication that the way courts handled the doctrine was considered to be a mischief. There is no indication that legislation was deemed required to remedy such mischief by limiting courts' discretion with regard to the purposes to which fair dealing might apply. Therefore, if Parliament did not consider the existing doctrine of fair use to cause any mischief, there is no reason to presume that Parliament had intended to restrict its application.

\section{Presumption that an Enactment Does Not Change Existing Law without Clear Indication}

The conclusion that Parliament had no intention to prevent the application of fair dealing to other purposes is further supported by the presumption that an enactment does not change the existing law without clear indication, and by the interpretative rule that an enactment is presumed to create absurd results. As Sullivan writes, "despite the constitutional primacy of the legislature...it is presumed that the legislature does not intend to change the common law, to introduce exceptions to general principles (which often originate in the common law), to interfere with common law rights and freedoms, or to take away the jurisdiction of common law courts." 223 To interpret an enactment otherwise requires clear indication. This principle was well recognized at the time of the enactment of the 1911 Act.224

Indeed, the drafters of the 1911 Act were clearly cognizant of these principles, because when Parliament wished to deviate from 
the common law, it did so explicitly. For example, section 31 of the 1911 Act was titled "Abrogation of common law rights", and provided that: "No person shall be entitled to copyright... whether published or unpublished, otherwise than under and in accordance with the provisions of this Act, or of any other statutory enactment for the time being in force, but nothing in this section shall be construed as abrogating any right or jurisdiction to restrain a breach of trust or confidence." This provision was meant to settle once and for all the uncertainty with respect to whether there existed a "common law copyright" independent of the statute. .255 At the same time, Parliament clarified that "the abrogation of common law rights only applie[d] to the common law proprietary right" 226 but did not affect other common law causes of action. 227 The provision, with almost identical wording, constitutes section 89 of the current Copyright Act.228

While section 31 explicitly abrogated some common law rights, section 6(1) of the 1911 Act (and the corresponding section 34(1) in the current $A c t$ ) explicitly invite courts to resort to the common law when deciding the proper remedy when infringement has been found. $\frac{229}{}$ Notably, neither section 31 nor section 6(1) limit any common law rights of users or any common law defense that might be applicable. If Parliament was interested in restricting users' rights or limiting the common law defenses that may be applicable to them, it would have done that explicitly.

The choice of the terms "fair" or "fair dealing" also indicate the legislative intent to maintain continuity with the pre-enactment case law. Notably, in the 1937 case of Johnstone $v$ Bernard Jones, both parties agreed that while the case had to be decided according to the statutory provision, the previous case law on what constituted "fair use" was relevant and helpful. The plaintiff went even further and maintained that "It is notorious that the Copyright Act, 1911, was an attempt to codify the law: and it would be strange if the Legislature consented to accept from the draftsman the word 'fair' with a different meaning from that which it had in the cases decided before 1911."230

Even though there is no indication that Parliament intended to restrict fair dealing and displace the common law doctrine with a more restrictive statutory version, it may still be unclear whether the intention was (1) merely to incorporate or codify the common 
law principle without an intention to modify it, except that its future development will be based on the statute and not on the common law; (2) to supplement the common law without displacing it (in which case the statutory fair dealing continues to exist alongside a common law fair use); or, alternatively, (3) to supplement the common law without creating conflict, but with the intention of replacing the common law with an exhaustive statutory scheme. .31

While Viscount Haldane's statement that section 2(1)(i) merely "declare[s]...for the future the principle of fair dealing which the Courts have established is to be the law of the Code" seems consistent with the first interpretive alternative, there are some aspects in which the statutory fair dealing supplements the common law: first, it explicitly recognizes that "private study", "research" and "newspaper summary" could be considered fair dealing, even though there was no previous case law dealing with the latter and there was case law that might have implied that the doctrine did not apply to the former. ${ }^{232}$ Second, prior case law often disposed of cases of copying of insubstantial part as a matter of fair use, but the statutory scheme created a distinction between the two concepts. Copying of an insubstantial part did not constitute an infringement by virtue of the definition of the copyright in section 1(1) (currently section 3(1) in Canada), whereas fair dealing would not constitute an infringement by virtue of the proviso in section 2(1)(i) (currently ss 29-29.2 in Canada), meaning that fair dealing may apply-and indeed should only be considered-if what has been copied is substantial. $\underline{233}$ Therefore, the first alternative (codification without any modification) may not be the correct one.

The second alternative-namely, that the statutory fair dealing coexists with a common law fair use-may be an attractive way of interpreting the current fair dealing provisions, because it allows the court easily to reconcile the plain language of the fair dealing provisions with the other considerations militating against the view that fair dealing is confined to the five enumerated purposes. Recognizing that a common law fair use continues to coexist alongside the statutory fair dealing allows the court to avoid two evils: one, an interpretation of the Act that may seem to be reading into it language that is not there (e.g., reading in the words "such as", or interpreting the five enumerated purposes so broadly in order to capture the impugned 
use), ${ }^{234}$ and, two, the absurd results arising from an interpretation that views all fair dealings for purposes beyond the five enumerated ones as categorically infringing, no matter how otherwise fair those dealings are.

The difficulty may lie in reconciling this approach with the Compo legacy: the Supreme Court's statement that "The legislation speaks for itself and the actions of the appellant must be measured according to the terms of the statute, $\underline{235}$ and that "copyright in this country is a creature of statute and the rights and remedies it provides are exhaustive". $\underline{236}$ Perhaps it is time to add some nuance to these statements. $\underline{237}$

The third alternative may seem more consistent with Viscount Haldane's statement, and with the Compo legacy, but it will require courts to either interpret each of the enumerated purposes so broadly as to encompass any possible use that may deem to be fair, or to recognize that the list of enumerated purposes is after all, and contrary to conventional wisdom, not exhaustive. A court may do so either by interpreting the list as merely illustrative of a broader principle that underlies fair dealing, or by acknowledging the occasional imperfections of statutory drafting and reading in the words "such as".

\section{Avoiding Absurd Consequences}

As noted above, the notion that by enumerating the five (now eight) categories, Parliament intended to exclude all possible other instances of fair dealing is linguistically plausible. But what is linguistically plausible is not determinative of the text's legal meaning. " $[\mathrm{T}]$ he linguist inquires into what meanings the text can 'tolerate' in its language, in light of the totality of potential contexts. ... Legal interpreters build on the work of the linguists who determine linguistic range. Interpreters translate the language into law by pinpointing or extricating a single, unique legal meaning." 238 Among other consideration, the legal interpreter is directed to avoid an interpretation that produces absurd consequences. $\frac{239}{\text { " }}[\mathrm{A}] \mathrm{n}$ interpretation can be considered absurd if it leads to ridiculous or frivolous consequences, if it is extremely unreasonable or inequitable, if it is illogical or incoherent, or if it is incompatible with other provisions or with the object of the legislative enactment." 240 
A few examples will suffice to show that the view that the list of enumerated purposes is exhaustive leads to such absurd consequences. Consider, for example, the common-and indeed indispensablepractice in judicial proceedings whereby litigants make several copies of the authorities they rely on and submit them to the court and to all other parties. There is no explicit provision in the Copyright Act that permits this action, and the making of such copies does not easily fit any of the enumerated fair dealing provisions. Interestingly, the current UK legislation includes explicit provisions that permit the making of such copies, $\underline{241}$ but they did not exist in 1911, and cannot be found in the Canadian Act. ${ }^{242}$ Yet, in $\mathrm{CCH}$ the Court did not hesitate to endorse the Great Library's practice of making copies, which explicitly permitted the making of copies "required for the purposes of research, review, private study and criticism, as well as use in court, tribunal and government proceedings" $\underline{43}$ and concluded that "the Law Society's dealings with the publishers' works satisfy the fair dealing defence." 244 Even though Parliament never explicitly exempted this activity, the Court effectively recognized an additional implied fair dealing exception for this purpose, and rightly so. Doing otherwise would be utterly absurd. $\underline{245}$

Or consider time-shifting. In 1984, the US Supreme Court ruled, in the landmark Sony $v$ Universal case, that it was fair use-and therefore not an infringement of copyright-for individuals to use a video cassette recorder to tape television shows in order to view them at a later time. At the end of the majority opinion, after providing a detailed doctrinal analysis, Stevens J wrote the following epilogue:

One may search the Copyright Act in vain for any sign that the elected representatives of the millions of people who watch television every day have made it unlawful to copy a program for later viewing at home, or have enacted a flat prohibition against the sale of machines that make such copying possible. $\underline{246}$

Should we assume that because time-shifting was explicitly recognized as non-infringing only in 2012 (and not as part of the fair dealing provision), 447 the elected representatives of millions of Canadians who have watched television every day and have taped 
TV shows for the better part of the last three decades have made it unlawful to videotape TV shows? Is there any valid political theory that would explain why Stevens J's assumption about the American political process could not apply to Canada in this context? And what about a person who made two copies of a TV show: to begin watching one at home, and continue watching it on an iPad at the gym? The new time-shifting exception in section 29.23(c) covers only the making of one reproduction. Does the second one necessarily make that person an infringer? Do we really need to try shoehorning this activity into one of the enumerated purposes to avoid this absurdity? $\underline{248}$

Should we assume that Justin Bieber infringed copyright when, in 2008, he posted on YouTube videos of himself singing others' songs without first clearing the copyrights, $\frac{249}{}$ and that this kind of activity was made lawful only in 2012, when section 29.21 was enacted?

Or consider section 29.4, permitting common classroom activities, such as writing a poem on a blackboard or incorporating an image into an overhead presentation. This provision was enacted in 1997, meaning that until that year, there was no explicit provision permitting those activities. While PowerPoint presentations did not exist in 1911-and likely were not even contemplated then-chalk, blackboards and poems clearly did. It would be absurd to think that for the better part of the twentieth century, writing a poem on a blackboard in a classroom required the permission of the copyright owner, and that Parliament intended this result, but changed its mind in 1997. Likewise, it would be absurd to think that any deviation from the requirements of section 29.4, even after 1997 (e.g., if the copying is done not "on the premises of an educational institution", but during a field trip, or if an image is being photocopied and distributed as handouts, but not displayed on a board or projected) would constitute infringement without the consent of the copyright owner. Strange as it may sound, this would have been the implication of the minority view in Alberta $v$ Access Copyright, had this view prevailed. 250

Fortunately, this interpretive challenge is now moot, because the Supreme Court confirmed that "private study" includes classroom instruction, and Parliament added "education" to section 29, an amendment that removes any doubt about the availability of fair dealing to these circumstances. 
Moreover, the notion that fair dealing applies only to certain allowable purposes implies that "[d]ealings for other purposes are not covered by the exception, even if they would otherwise be fair". This means that when Parliament enacted in 1911 that "Any fair dealing with any work for the purposes of private study, research, criticism, review, or newspaper summary...shall not constitute an infringement of copyright", it meant that dealings with works for other purposes may still be regarded as fair, but nonetheless shall constitute an infringement of copyright. As noted above, this is a paradoxical result.

Finally, and more generally, the notion that Parliament intended to exclude the possibility of applying fair dealing to non-enumerated purposes necessarily relies on one of the following two alternative assumptions: one, that Parliament believed that it had canvassed the entire universe of uses that were known at the time of the enactment as well as those that might be known and possible sometime in the future, and concluded that only the five (and now eight) enumerated purposes are capable of qualifying as fair dealing; or that Parliament was aware it could not foresee all potential future uses, but still decided in advance that no matter what those uses are, they ought to be categorically excluded.

The first alternative is inconsistent with the "basic assumption that the legislature is a competent institution acting in the public interest." 252 No competent legislature could believe that it could foresee all types of future uses and predetermine that they could not possibly be fair.

The absurdity of the alternative assumption requires more elaboration. The absurdity of the notion that if a purpose is not explicitly enumerated, it is categorically excluded from the purview of fair dealing, stems from its incompatibility with the purpose of the Copyright Act.

Fair dealing has a purpose: to allow the unauthorized use of works in a manner that promotes the public interest in the encouragement and dissemination of works of the arts and intellect, when the dealing does not seriously undermine the copyright owner's opportunity to obtain a just reward. ${ }^{253}$ It is the same purpose identified by Lord Mansfield in 1785, $\stackrel{254}{ }$ Souter J in $1995 \frac{255}{2}$ or the Supreme Court of Canada in 2004 and 2012. 
Yet, even though it is possible to identify the principle that fair dealing stands for, articulating a precise legal rule that implements it is notoriously difficult, if not impossible. The Royal Commission on Copyright, whose 1878 report was one of the bases for the enactment of the Copyright Act, 1911, stated that "no principle which we can lay down, or which could be defined by the Legislature, could govern all cases that occur" and that ultimately these can be decided only on a caseby-case basis by "the proper tribunals." $\stackrel{256}{ }$ Almost a century later, the US Congress House Committee reached a similar conclusion, noting that "since the doctrine is an equitable rule of reason, no generally applicable definition is possible, and each case raising the question must be decided on its own facts." $\stackrel{257}{ }$ Lord Denning, in Hubbard $v$ Vosper,, 258 and the Court, in $\mathrm{CCH}$, made similar observations, as did the US Supreme Court in Campbell. .59

It is not surprising, therefore, that instead of precise rules, legislation that includes fair dealing or fair use provisions tends to adopt a flexible and adaptable standard, $\underline{260}$ to be implemented by courts on a case-by-case basis or, more often, a combination of a general governing fair dealing standard, supplemented by specifically proscribed rules applicable to certain circumstances that were identified in advance.

Similarly, at the international level, attempts to draft a precise rule regarding limitations and exceptions to copyright proved futile, and resulted in the intentionally vague three-step test, such as the one incorporated in the Berne Convention. $\frac{261}{6}$

Once the central role that fair dealing plays in calibrating the rights of owners with the rights of users and the public interest is recognized, the view that fair dealing applies only to the explicitly enumerated purposes becomes tenuous, because it requires one to believe that those five, now eight, purposes encompass the entire universe of dealings that could justify using a work without getting the copyright owner's permission. But it is easy to identify uses that do not fall into any of the enumerated purposes (or any other specific statutory exception) and that Parliament cannot have intended to be regarded as categorically infringing.

But more importantly, if the purpose of the Copyright Act is to encourage future innovation and creativity, fair dealing must be 
flexible and unlimited with respect to the purposes to which it could apply, otherwise this purpose would be undermined. Rule makers cannot foresee all the types of future uses that justify exemption, and inevitably, a system that relies exclusively on ex ante proscribed rules will be tailored to allow only the interests of existing users who had enough political clout to lobby for an exemption. ${ }^{262}$ By definition, however, truly new innovations in technology or in cultural expression, those that do not yet exist and may not even be thought of, have no one advocating for them. $\frac{263}{3}$ Without a possibility of relying on a flexible fair dealing standard, the law might prevent these innovations from ever being created. A system that permits only the uses that were able to bargain their way at the legislative negotiation table but excludes all others is doomed to cultural and technological stagnation. While a flexible fair dealing does not guarantee that all socially beneficial uses will be permitted, at least it allows the new uses, those that were not even thought of, or that had no one lobbying for them during the legislative process, to have their day in court and argue, "We're fair!" It allows innovators to use their scarce resources on recruiting the most talented developers before they need to hire the lobbyists. $\frac{264}{}$ Not all such uses or expressions are necessarily fair, but a rule that categorically excludes them from the purview of fair dealing means that they require prior permission from either the copyright owner or from Parliament. If such an outcome does not constitute an outright unconstitutional prior restraint on speech, then it is at least very close, and "the traditional reticence of English, American, and Canadian courts to impose prior restraints on speech" 265 ought to disfavour it. $\underline{266}$

Leaving room to individual litigants and the courts to apply fair dealing to circumstances unforeseen by Parliament is not a "far less effective, less democratic and less principled way to approach copyright reform" $\stackrel{267}{ }$ than the alternative. Quite the contrary: it is more effective, more democratic and more principled, because it enables policy making based on evidence and arguments that are inherently incapable of having a voice in the legislative process. $\frac{268}{}$ It is a feature, not a bug.

Moreover, specific rule-based exceptions, whose main advantage is the certainty that they are purported to promote, are vulnerable to rigidity, and without an overarching principle to guide them, their application tends to "hinge on arcane debates over taxonomy 
[making them] perennially uncertain." 269 In contrast, an omnipresent flexible fair dealing avoids this rigidity, and increases certainty over time, as the contours of owners' and users' rights in unforeseen circumstances is determined through litigation,,$\underline{270}$ and subsequent legislative amendments when necessary.

\section{V: Conclusion}

When fair dealing was codified a century ago, there was no intention to restrict or limit its application, adaptation and adjustment by the courts. Parliament sought to codify a principle, a flexible standard, not precise rules, yet the English courts that failed to recognize this point have sentenced fair dealing to a hundred years of solitude. Fortunately, at the turn of the twenty-first century, the Supreme Court of Canada declined to follow that restrictive path. Parliament's decision to explicitly recognize additional purposes and add specific exceptions moves Canadian law in the same direction. The Court's rulings and Parliament's action have entrenched fair dealing and provided a necessary correction that allows fair dealing to resume the role it was always supposed to play. The recent developments have narrowed the range of potential uses that may not be found within the ambit of the explicit exceptions, or the more general fair dealing provisions, but if conventional wisdom is correct, some uses, present or future, are still categorically excluded. This is not a recipe for progress. We can easily predict that fewer new forms of expressions, and fewer novel ways of using, reusing and disseminating works, will emerge in a legal environment that outlaws them outright.

However, there is no serious indication that this is what Parliament intended when it legislated fair dealing, and there are very good reasons to challenge the view that it did have such intentions. "All we propose," declared Viscount Haldane before the House of Lords in 1911, "is to declare that for the future the principle of fair dealing which the Courts have established is to be the law of the Code."271 All I propose is that we follow that law.

Omnipresent fair dealing is here. It always has been. 
1 In November 2011, the Centre for Innovation Law and Policy at the Faculty of Law, University of Toronto filed an Intervener Factum in Alberta (Education) $v$ Access Copyright (SCC 33888). Howard Knopf and I wrote that factum; this chapter is based in part on the research conducted in its preparation. Howard Knopf deserves much credit for helping me develop some of the ideas in this chapter, as well as for being instrumental in distilling them into a ten-page factum. I also wish to thank Abbas Kassam, Rachel Weinberg, and David Yi for their research assistance, as well as Aharon Barak, Barton Beebe, Michael Birnhack, Oren Bracha, Carys Craig, Abraham Drassinower, Richard Ellis, Brett Frischmann, Jeanne Fromer, Tomas Gomez-Arostegui, Bill Patry, Matthew Sag, and Simon Stern for their various comments and suggestions.

2 Interestingly, Australia enacted a fair dealing provision in 1905. Section 28 of the short-lived Copyright Act 1905 (Cth) provided that "[A] book shall not be infringed by a person making an abridgement or translation of the book for his private use (unless he uses it publicly or allows it to be used publicly by some other person), or by a person making fair extracts from or otherwise fairly dealing with the contents of the book for the purpose of a new work, or for the purposes of criticism, review, or refutation, or in the ordinary course of reporting scientific information." This provision was apparently taken from cl 4(5) of the failed UK's Copyright Bill 1900 (no 295) (An Act to Amend and consolidate the Law relating to Literary Copyright); see Alexandra Sims, "Strangling Their Creation: The Courts' Treatment of Fair Dealing in Copyright Law Since 1911" (2010) 2 Intell Prop Q 192 [Sims, "Strangling Their Creation"]. The 1905 Act was replaced with the Copyright Act 1912 (Cth), which adopted the Copyright Act 1911 (UK), 1 \& 2 Geo V, c 46.

s Ibid.

4 CCH Canadian Ltd. v Law Society of Upper Canada, 2004 SCC 13, [2004] 1 SCR $339<$ http://www.canlii.org/en/ca/scc/doc/2004/2004scc13/2004scc13.html $>$ [CCH].

5 Ibid at paras 48,51 .

6 Society of Composers, Authors and Music Publishers of Canada v Bell Canada, 2012 SCC36, [2012]2SCR326<http://canlii.ca/en/ca/scc/doc/2012/2012scc36/2012scc36. html $>[$ Bell]. Alberta (Education) v Canadian Copyright Licensing Agency (Access Copyright), 2012 SCC 37 at para 19, [2012] 2 SCR $345<$ http://canlii.ca/en/ca/sccl doc/2012/2012scc37/2012scc37.html $>$ [Alberta (Education)].

7 Copyright Modernization Act, SC 2012, c $20<$ http://laws-lois.justice.gc.ca/eng/ AnnualStatutes/2012 20/FullText.html>, amending the Copyright Act, SC, c C-42, s 29.

8 Ibid, ss 29.21, 29.22, 29.23, 30.71.

9 Since this Chapter focuses on Canada, I will leave the question of whether fair dealing has been irrevocably ossified in the UK to others.

10 See e.g. David Vaver, Intellectual Property Law: Copyright, Patents, Trade-marks, 2d ed (Toronto: Irwin Law, 2011) at 234; Lior Zemer, "Copyright Departures: The Fall of the Last Imperial Copyright Dominion and the Case of Fair Use" (2011) 60 DePaul L Rev 1051 at 1068; Louis Grilli et al, "Fair Dealing or Fare Stealing?: Implications of Canadian Copyright Law Reform on the Online Classroom" (2010) 7:2 CJLT 267; Giuseppina D’Agostino, "Healing Fair Dealing? A Comparative Copyright Analysis of Canada's Fair Dealing to U.K. Fair Dealing and U.S. Fair Use" (2008) 53:2 McGill LJ 309 at 314; David Bradshaw, "Fair Dealing as a Defence 
to Copyright Infringement in UK Law: An Historical Excursion from 1802 to the Clockwork Orange Case 1993" (1995) 10 Denning LJ 67 at 71 . Until recently, I echoed this view, too; see Ariel Katz, "What Can Canada Learn from Israel about Copyright Reform?" (10 December 2007), University of Toronto Law School Faculty Blog < http://web.archive.org/web/20071210161010/http://utorontolaw.typepad. com/faculty_blog/2007/12/what-can-canada.html>.

11 Barry Sookman \& Dan Glover, "Why Canada Should Not Adopt Fair Use: A Joint Submission to the Copyright Consultation" (2009) 2:2 Osgoode Hall Rev L Pol'y 139 at $157<$ http://ohrlp.ca/wp-content/uploads/2012/10/why-canada-should-notadopt-fair-use.pdf $>$.

12 Copyright Act, 17 USC $\$ 107$ (US): ("Notwithstanding the provisions of sections 106 and 106A, the fair use of a copyrighted work, including such use by reproduction in copies or phonorecords or by any other means specified by that section, for purposes such as criticism, comment, news reporting, teaching (including multiple copies for classroom use), scholarship, or research, is not an infringement of copyright. ...").

$\underline{13}$ These are the five enumerated categories that originally appeared in s 2(1)(i) of the 1911 Act.

14 Copyright Act, supra note 7, ss 29-29.2.

15 See Sookman \& Glover, supra note 11. See also Bell, supra note 6 at paras 24-26.

16 Alberta (Education) v Access Copyright, [2009] CBD No 6 at para 77 (rev'd) [Alberta (Education) (CB)]; see also CCH Canadian Ltd. v Law Society of Upper Canada, 2002 FCA 187 at para 127 (reversed on other grounds) <http://canlii.ca/ en/ca/fca/doc/2002/2002fca187/2002fca187.html $>[C C H(F C A)]$.

17 The closest case is Hawkes \& Son (London), Ld. v Paramount Film Service, Ld. (1934), 11934 Ch 593, discussed infra, in part III.C.3 [Hawkes \& Son].

$\underline{18} \mathrm{Ibid}$ at 608 . (Slessel J, "It is impossible to say that this reproduction in a film of sound can be a newspaper summary. I think this proviso must be dealt with strictly, and when it says 'newspaper summary' it means newspaper summary and nothing else.")

19 Ibid; Alberta (Education), supra note 6 at para 19; .

20 Compo Co. Ltd. v Blue Crest Music et al., [1980] 1 SCR 357 at 366-67, 1979 CanLII

$6<$ http://canlii.ca/t/1mjth $>$ [Compo].

$\underline{21}$ Ibid.

$\underline{22}$ US Const art I, $\$ 8, \mathrm{cl} 8$.

$\underline{23}$ There is no consensus, however, about nature and scope of those limitations. See e.g., Jeanne C Fromer, "The Intellectual Property Clause's External Limitations" 61 Duke LJ 1329. See also Dotan Oliar, "Making Sense of the Intellectual Property Clause: Promotion of Progress as a Limitation on Congress's Intellectual Property Power" 94 Geo LJ 1771.

$\underline{24}$ The Constitution Act, 1867 (UK), 30 \& 31 Vict, c 3, reprinted in RSC 1985, App II, No 5.

$\underline{25}$ It might be argued that the choice of the terms "patents for inventions and discovery" and "copyrights" actually embodies some substantive limitations; see infra note 35 and surrounding text.

$\underline{26}$ Oren Bracha, "The Adventures of the Statute of Anne in the Land of Unlimited 
Possibilities: The Life of a Legal Transplant” (2010) 25 Berkeley Tech LJ 1427 at 1445 [Bracha, "Statute of Anne"]. Bracha also describes how the first US Copyright Act, enacted in 1790, was a mere copy of the Statute of Anne, and had the same title. See also Michael D Birnhack, "The Idea of Progress in Copyright Law" 1 Buff IP LJ 3, text surrounding n 181 . The term "science" in 1790 had a broader meaning than today and was synonymous with "knowledge" or "learning", see ibid, text of n 178.

27 Birnhack, supra note 26.

$\underline{28}$ Ibid.

29 Ibid at $\mathrm{n} 91$.

30 Sayre v Moore (1785), 1 East 361, 102 ER 139 (KB) at 139. Compare Théberge v Galerie d'Art du Petit Champlain inc., 2002 SCC 34, [2002] 2 SCR 336 [Théberge]: "Excessive control by holders of copyrights and other forms of intellectual property may unduly limit the ability of the public domain to incorporate and embellish creative innovation in the long-term interests of society as a whole, or create practical obstacles to proper utilization."

31 Cary v Kearsley (1802), 4 Esp 168, 170 ER 679 at 680.

32 An Act to amend the Law of Copyright (UK), 1842, 5 \& 6 Vict, c 45.

$\underline{33}$ Campbell v Acuff-Rose Music, Inc. (1994), 5101994 US 569 <http://www.law. cornell.edu/supct/html/92-1292.ZS.html> [Campbell v Acuff-Rose].

34 Souter J did not reference only the US Constitution, but also supports the proposition with references to English law. Ibid. See also Barry Torno, Fair Dealing: The Need for Conceptual Clarity on the Road to Copyright Revision (Copyright Revision Studies, Research and International Affairs Branch, Bureau of Corporate Affairs, Consumer and Corporate Affairs Canada, 1981) at 57 (and further references therein, noting that American and Canadian copyright laws are predicated on the same scheme, as descendants of the Statute of Anne).

$\underline{35}$ Possibly, the terms "patents of inventions and discovery" and "copyrights" distinguishes those two types of statutory grants from other types of exclusive rights or monopolies whose grant remained outside the scope of Parliament's legislative power, and within exclusive Provincial jurisdiction as matters of Property and Civil Rights (and subject to the Statute of Monopolies in those Provinces where it is in force), see Harold G Fox, "Abuse of Monopoly" [1945] 23:5 Can Bar Rev 353 at 363.

36 Darcy v Allen (1603), 11 Co Rep 84b.

$\underline{37}$ (1624) $21 \mathrm{Jac}$ I, c 3.

$\underline{38}$ Bracha, "Statute of Anne", supra note 26 at 1450.

39 (1769) 4 Burr 2203; 98 ER 201.

$\underline{40}$ (1774) 4 Burr 2408.

41 Oren Bracha, "Commentary on: The Constitutional Copyright Clause (1789)" (2008), online: Primary Sources on Copyright (1450-1900) <http://copy.law. cam.ac.uk/cam/tools/request/showRecord?id=commentary us 1789> [Bracha, "Commentary"].

42 Melissa de Zwart, "An Historical Analysis of the Birth of Fair Dealing and Fair Use: Lessons for the Digital Age" (2007) 1 Intell Prop Q 60 at 70-71.

$\underline{43}$ (1854) 4 HLC 815. 
$\underline{44}$ Ronan Deazley, Rethinking Copyright, History, Theory, Language (Cheltenham, UK: Edward Elgar, 2006) at 52.

$\underline{45}$ Compare Compo, supra note 20 at 373 (stating that copyright is "This creature of statute [that] has been known to the law of England at least since the days of Queen Anne when the first copyright statute was passed").

$\underline{46}$ Bracha, "Commentary", supra note 41.

$\underline{47} 17$ USC $\$ 301$ (US).

$\underline{48}$ David Schneiderman, "Property Rights, Investor Rights, and Regulatory Innovation: Comparing Constitutional Cultures in Transition" (2006) 4 ICON 371 at 378 .

$\underline{49}$ See e.g. Scott $v$ Stanford (1867), LR 3 Eq 718 at 722 (quoting Story J's famous formulation of fair use in American law from Folsom v Marsh, 9 F Cas 342 (CCD Mass 1841), and noting that " $\mathrm{t}]$ he general principles guiding the Court in cases of this description could hardly be found better stated" than in that case).

$\underline{50}$ E.g. Matthew Sag, “The Pre-History of Fair Use" SSRN (2011) 76:4 Brook L Rev $1371<$ http://ssrn.com/abstract=1663366 > ; Alexandra Sims, "Appellations of Piracy: Fair Dealing's Prehistory" (2011) Intell Prop Q 3 [Sims, "Appellations of Piracy"]; William F Patry, The Fair Use Privilege in Copyright Law, 2d ed (Washington, DC: Bureau of National Affairs, 1995).

$\underline{51}$ Ibid.

$\underline{52}$ Ibid.

$\underline{53}$ Folsom v Marsh, supra note 49.

${ }_{54}$ Patry, supra note 50.

$\underline{55}$ Hotter v Arthur (1863), 1 H\&M 603 at 609; EJ MacGillivray, The Copyright Act, 1911, Annotated (London: Stevens \& Sons, 1912) at 29.

56 Chatterton v Cave (1878), 3 App Cas 483 (HL) at 492.

57 Vaver, supra note 10 at 187-88.

58 Cambridge University Press v Becker, 863 F Supp (2d) 1190 (ND Ga 2012) at 1225 ("It is generally recognized that 'Under [the second] factor, the more creative a work, the more protection it should be accorded from copying; correlatively, the more informational or functional the plaintiff's work, the broader should be the scope of the fair use defense.' 4-13 Nimmer on Copyright, $\$ 13.05[\mathrm{~A}][2][\mathrm{a}] . ")$

59 Lewis v Fullarton (1839), 2 Beav 6, 48 ER 1080. See also Bradshaw, supra note 10 at 68 .

60 Wilkins $v$ Aikin (1810), 17 Ves Jun 422, 34 ER 163 at 164 per Lord Chancellor Eldon: "There is no doubt, that a man cannot under the pretence of quotation, publish either the whole or part of another's work; though he may use, what it is in all cases very difficult to define, fair quotation."

61 Lord Perceval v Phipps (1813), 2 V \& B 19.

62 Gyles $v$ Wilcox (1740), 2 Atk 141, 26 ER 489 at 490.

63 Millar v Taylor (1769), 4 Burr 2303, 98 ER 201 at 205. See generally Saul Cohen, "Fair Use in the Law of Copyright" (1955) 6 Copyright L Symp 43 at 48.

64 The term "fairly dealing" was used in the Copyright Bills of 1900 and 1910, and in the Australian Copyright Act 1905; see Sims, "Appellations of Piracy", supra note 50 at 3.

$\underline{65}$ Sims hypothesizes that substituting "fair dealing" for "fair use" may be attributed 
"to the acrimonious relationship at that time between Britain and the United States over copyright law. Britain may have been reluctant to use 'fair use' because that term was in common use in the United States" and chose a term that had been already in use in Australia, see ibid. Since the term "fair use" was also in common use in Britain, and was not the only term used in the copyright laws of both countries, it is not clear why the international politics of copyright would cause Britain to change this particular term.

66 Robert Burrell \& Allison Coleman, Copyright Exceptions: The Digital Impact (New York: Cambridge University Press, 2005). This expansion would finally be codified in the notion of "substantial part" in s 2 of the 1911 Act. See also Sag, supra note 50.

67 Burrell \& Coleman, supra note 66 . This expansion would finally be codified in the notion of "substantial part" in s 2 of the 1911 Act.

68 CCH, supra note 4.

69 JM Easton, The Law of Copyright in Works in Literature, Art, Architecture, Photography, Music and the Drama by the Late Walter Arthur Copinger, 5th ed (London: Stevens \& Haynes, 1915) at 144 [Copinger on Copyright, 5th ed].

$\underline{70}$ de Zwart, supra note 42 at 160.

71 Cary v Kearsley, supra note 31 at 680 .

72 North American Free Trade Agreement Implementation Act, SC 1993, c 44, s 64(1).

$\underline{73}$ John S McKeown, Fox on Canadian Law of Copyright and Industrial Designs (Toronto: Thomson Carswell, 2003) s 23:2(c), loose-leaf, Rel 4, 2010.

74 An Act to amend the Copyright Act, SC 1997, c 24, s 18(1).

75 The Latman Study, one of the preliminary studies that lead to the enactment of s 107 reviewed previous attempts to codify fair use since the passage of the US Copyright Act, 1909. Some proposals explicitly suggested adopting the UK provision. One of them, from 1940, proposed a provision protecting "fair dealing" for "the purpose of private study, research, review or newspaper summary." ... The entire section was deleted after the Joint Committee on Materials for Research, apparently considering "the position of the scholar more favorable under the case law, convinced all other interested groups except the book publishers that the attempt to codify the doctrine of fair use had been unsuccessful"; see Allen Latman, Study 14: Fair Use of Copyrighted Works (U.S. Copyright Office, 1958).

76 For discussions of these and additional cases, see Burrell \& Coleman, supra note 66 at 260-63; Sims, "Strangling Their Creation", supra note 2.

77 Carys Craig, Copyright, Communication and Culture: Towards a Relational Theory of Copyright Law (Northampton, MA: Edward Elgar, 2011) at 160. See also Sims, "Strangling Their Creation", supra note 2.

78 University of London Press, Ltd. v University Tutorial Press, Ltd. (1916), $21916 \mathrm{Ch}$ 601 [University of London].

$\underline{79}$ It took Canadian law almost a century to lay some of its problematic legacy to rest, first in $\mathrm{CCH}$, with regard to the meaning of "originality", and then in Alberta (Education), with regard to the misinterpretation of the case's holding about the meaning of "private study".

80 University of London, supra note 78 at 613. 
$\underline{81}$ Ibid.

82 Ibid at 604-05.

$\underline{83}$ Ibid at 605 .

$\underline{84}$ Ibid at 606.

85 Ibid at 606-07.

86 Ibid at 613-14 [emphasis added].

87 FE Skone James, Copinger on the Law of Copyright, 6th ed (London: Sweet \& Maxwell, 1927) at 123 [Copinger on Copyright, 6th ed].

88 CCH (FCA), supra note 16 at para 129.

$\underline{89}$ Ibid at para 130.

90 Alberta (Education) (CB), supra note 16 at para 90.

91 Alberta (Education), 2010 FCA 198 at para $39<$ http://canlii.ca/en/ca/fcal doc/2010/2010fca198/2010fca198.html> [emphasis added].

92 University of London, supra note 78 at 614 [emphasis added].

93 Alberta (Education), supra note 6 at para 21. This interpretation of University of London was one of the key arguments in the CILP Intervener Factum, supra note 1.

94 British Oxygen v Liquid Air (1925), 1 Ch 383 [British Oxygen].

95 Ibid at 386-88.

96 Ibid at 393.

97 Ibid at 385 . The defendant was probably referring to the same cases discussed at the House of Commons, infra note 185 and surrounding text.

98 Ibid at 393.

99 Ibid at 393-94.

100 Hawkes \& Son, supra note 17.

101 Ibid at 595.

102 Ibid at 598.

103 Ibid.

104 Ibid.

105 Ibid at 599.

106 Ibid at 600 .

$\underline{107}$ Ibid at 599.

108 Infra part IV.B.

$\underline{109}$ Re Mayfair Property Co, [1898] 2 Ch 28 at 35, Lindley MR.

$\underline{110}$ R. v Morgentaler, [1993] 3 SCR 463 at $484<$ http://canlii.ca/en/ca/scc/doc/1993/1 993canlii74/1993canlii74.html>.

111 Hawkes \& Son, supra note 17 at 600 .

$\underline{112}$ Ibid at 595 .

$\underline{113}$ Ibid at 602 .

114 Ibid.

115 Entertainment Software Association v Society of Composers, Authors and Music Publishers of Canada, 2012 SCC 34 at para 11, [2012] 2 SCR 231. 
116 Ralph Hawkes of Hawkes \& Son was a board member of the Performing Rights Society. The late 1920s were years of "sudden and seismic upheaval in the economics of the music trade", Hellen Wallace, Boosey \& Hawkes The Publishing Story (London, UK: Boosey \& Hawkes, 2007) at 7. Sales of sheet music, music publishers' main source of revenue, plummeted, as recorded and broadcast music and changing tastes led to a decline in the number of concerts and amateur music making, ibid at 8 , and saw further drastic decline after the arrival in Britain of The Jazz Singer. The ascendance of the "talkies" and the decline of the "silent" film meant that musicians were no longer necessary for accompanying movies with music, and an important market for sheet music disappeared immediately, ibid at 7 . This prompted music publishers to seek new revenue sources, and the case probably reflects such attempts. 117 Hawkes \& Son, supra note 17 at 602.

$118 \mathrm{Ibid}$ at 603. Compare Bishop v Stevens, [1990] 2 SCR 467 at para 21 (declaring that the benefit of authors of all kinds is the sole object of the Act) and para 22 (holding that the nature and purpose of the reproduction and whether it is prejudicial to the copyright owner are irrelevant considerations) with Bell, supra note 6 at paras 9-10 (acknowledging the shift in the Court's approach, away from Bishop $v$ Stevens' "author-centric view which focused on the exclusive right of authors and copyright owners to control how their works were used in the marketplace" to focusing "instead on the importance copyright plays in promoting the public interest, and emphasiz[ing] that the dissemination of artistic works is central to developing a robustly cultured and intellectual public domain."

119 Hawkes \& Son, supra note 17 at 604.

$\underline{120}$ Sims, "Strangling Their Creation", supra note 2 at 197.

$\underline{121}$ Ibid at 195.

122 Hawkes \& Son, supra note 17 at 603-08.

$\underline{123}$ Ibid at 608 .

$\underline{124}$ Ibid.

125 Ibid at 609 .

126 Copyright Act, 1956 (UK), 4 \& 5 Eliz II, c 74, s 6(3).

127 An Act to amend the Copyright Act, SC 1997, c 24, s 18(1).

128 Copyright, Designs and Patents Act 1988 (UK), c 48, s 31; Copyright Act, supra note 7 , s 30.7. Note, however, that the Canadian exception is drafted more restrictively. The Canadian exception contains two conditions: "incidentally and not deliberately", while the UK exception applies only to "incidental inclusion".

129 Hubbard $v$ Vosper, [1972] 2 QB 84 at 94.

130 Ibid.

$\underline{131}$ Beloff v Pressdram Ltd., [1973] FSR 33 at 38.

132 Pro Sieben Media AG v Carlton UK Television Ltd., [1999] FSR 610 (CA) at 614.

133 Allen v Toronto Star (1997), 36 OR (3d) 201 (Gen Div) at para 44.

$\underline{134} \mathrm{Ibid}$ at paras 39-40.

135 Aharon Barak, Purposive Interpretation in Law (Princeton, NJ: Princeton University Press, 2005) at 8.

136 Ibid. 
137 Ibid at 108-09.

138 Ruth Sullivan, Statutory Interpretation, 2d ed (Toronto: Irwin Law, 2007) at 193.

139 Isabella Alexander, Copyright Law and the Public Interest in the Nineteenth Century (Oxford: Hart, 2010) at 284.

$\underline{140}$ Alberta (Education) (CB), supra note 16 at para 77 (rev'd on other grounds).

$\underline{141}$ Oxford Dictionaries (Oxford University Press, April 2010) sub verbo "fair" (accessed 17 November 2012) <http://oxforddictionaries.com/definition/english/ fair>.

$\underline{142}$ CCH (FCA), supra note 14 at para 128.

$\underline{143}$ Ibid at para 129.

144 Alberta (Education), supra note 6 at para 47, Rothstein J, dissenting.

$\underline{145}$ Ibid at para 49 .

146 Ibid.

$\underline{147}$ The Oxford English Dictionary, 2d ed, CD-ROM (v 4.0.0.3), sub verbo "private".

$\underline{148}$ See e.g. s 3(1) (rights of "publication", "public performance", "communication to the public"), s 27(1)(c) ("by way of trade distribute, expose or offer for sale or rental, or exhibit in public").

149 Caird $v$ Sime (1878), 12 App Cas 326 (HL Sc).

$\underline{150}$ Ibid at 350 .

151 Ibid.

152 Ibid at 348 [emphasis added].

$\underline{153}$ Ibid at 349. Compare Alberta (Education), supra note 6 at para 23 (Abella J, "the teacher's purpose in providing copies is to enable the students to have the material they need for the purpose of studying. The teacher/copier therefore shares a symbiotic purpose with the student/user who is engaging in research or private study. Instruction and research/private study are, in the school context, tautological.").

154 Similarly, in Dickens v Hawksley, [1935] 1 Ch 267, the terms "instruction" and "private study" were used interchangeably by different judges, and were distinguished from "public" and "publication". The case involved a dispute between heirs of Charles Dickens over the copyright in his unpublished manuscript about the life of Jesus Christ. Bennett J, at 267, described the manuscript as "written for the instruction of the author's children and...not intended by him for publication". On appeal, Maugham LJ described the work as one "written by the author not for publication but for the benefit of his family, and...for their private study", ibid at 301 [emphases added]. Even though those two cases do not deal with fair dealing, their discussion of the meaning of "private" in pari materia of copyright legislation supports that that the term "private" in "private study" means not-public, rather than "by oneself".

155 Caird $v$ Sime, supra note 149 at 344 [emphasis added].

156 This interpretation is also consistent with MacGillivray's interpretation, supra note 55. According to MacGillivray, the right to use a work for private study gave a very broad liberty to copy works "So long as a work is utilised in this manner, solely for the personal instruction of the person so utilizing it", ibid at 27 . He also suggested that it also permitted multiplication of copies for the use of classes and societies, 
as long as such copying does not go beyond the limit of fairness. "The test will be whether there is a probability of substantial commercial injury ... to the copyright work", ibid at 27-28. See also a similar view in the 5th edition of Copinger, infra note 206 and surrounding text.

157 Compare SOCAN's argument that "research" meant "the systematic investigation into and study of materials and sources in order to establish facts and reach new conclusions" and that its goal "must be for the purpose of making creative works, since only uses that contribute to the creative process are in the public interest", Bell, supra note 6 at para 20.

158 In fact, if Rothstein J's interpretation of "private" was correct, this would mean that in 1997, Parliament actually spoke in vain when in s 80 it exempted certain copies "for the private use of the person who makes the copy." If "private" means "by oneself", there would be no reason to add "of the person who makes the copy".

159 Canada (Canadian Human Rights Commission) v Canada (Attorney General), 2011 SCC 53 at para 43, [2011] 3 SCR 471.

160 Francis Bennion, Statutory Interpretation, 3d ed (London, UK: Butterworth, 1997) at 458 ("The interpreter cannot judge soundly what mischief an enactment is intended to remedy unless he or she knows the previous state of the law, the defects found to exist in that law, and that facts that caused the legislator to pass the Act in question.") See also Ruth Sullivan, Sullivan on the Construction of Statutes, 5th ed (Markham, ON: LexisNexis, 2008) at 578 ("In tracing the evolution of a provision, an interpreter may begin by locating the first legislative formulation of the provision of the origin on the provision in common law case law.").

161 Great Britain, Royal Commission on Copyright, Report of the Commissioners (1897) at para 7.

162 MacGillivray, supra note 55 at iii-iv.

163 Ronan Deazley (2008) “Commentary on the Royal Commission's Report on Copyright (1878)", Primary Sources on Copyright (1450-1900) website, L. Bently \& M. Kretschmer, eds < www.copyrighthistory.org $>$ [Deazley, "Commentary"].

164 MacGillivray, supra note 55 at iv.

165 Copyright Act 1842 (UK), 5 \& 6 Vict, c 45.

166 George Stuart Robertson, The Law of Copyright (Oxford: Clarendon Press, 1912) at 15. (“The words 'any substantial part thereof' express meaning of what has been decided under the Copyright Act, 1842, upon the construction of the phrase, 'multiplying copies.' The sole right of making copies is held to include the sole right of making copies of any part. This deduction, coupled with the maxim, de minimis non curat lex, resulted in the decisions to the effect that it was an infringement to take a substantial part, but that it was not an infringement to take an insignificant particle.")

167 Copyright Act 1842 (UK), supra note 165.

168 The title of s 15 was "Remedy for the Piracy of Books by Action on the Case" and it read: "And be it enacted, That if any Person shall, in any part of the British Dominions, after the passing of this Act, print or cause to be printed, either for Sale or Exportation, any Book in which there shall be subsisting Copyright, without the Consent in Writing of the Proprietor thereof, or shall import for Sale or Hire any such Book so having been unlawfully printed from Parts beyond the Sea, or, knowing 
such Book to have been so unlawfully printed or imported, shall sell, publish, or expose to Sale or Hire, or shall have in his Possession for Sale or Hire, any such Book so unlawfully printed or imported, without such Consent as aforesaid, such Offender shall be liable to a special Action on the Case at the Suit of the Proprietor of such Copyright, to be brought in any Court of Record in that Part of the British Dominions in which the Offence shall be committed...", ibid.

169 Copyright Act, supra note 7, s 27(2).

170 Novello $v$ Sudlow (1852), 12 CB 177.

171 Ibid.

172 The reasoning of Novello $v$ Sudlow was also followed in Ager $v$ Peninsular and Oriental Steam Navigation Company (1882), 26 Ch D 637, where the court ruled against the defendant who incorporated substantial parts of the plaintiff's work in an internal company document, which was distributed among the defendant's employees and agents, but never sold or distributed to the public. Relying on Novello, the court held that the "it has long been settled that multiplying copies for private distribution among a limited class of persons is just as illegal as if it were done for the purpose of sale," ibid at 641. See also Warne \& Co. v Seebohm (1888), 39 Ch D 73.

$\underline{173}$ Provisions dealing with "secondary infringement" similar to those available under s 15 of the 1842 Act were included in s 11(1), the precursor of the present $\mathrm{s}$ 27(2) of the Canadian Act.

$\stackrel{174}{ }$ Royal Commission, supra note 161 at para 67.

175 Interestingly, in 1909, US Congress consciously decided to leave the determination of fair use entirely to the courts and the Act of 1909 remained, like its predecessors, entirely silent on this issue; Latman, supra note 75.

176 MacGillivray, supra note 55 at 27.

$\underline{177}$ Ibid at 28.

178 Supra note 168 and surrounding text.

$\underline{179}$ Alexander, supra note 139 at 283.

180 Alexander explains that a previous provision that appeared in the 1910 Bill was vehemently opposed by music publishers and other copyright owners' organizations. The 1910 proposal was broader than the 1911 provisions in some aspects and narrower in some others. It was broader in specifying a greater number of explicitly mentioned purposes that were deemed non-infringing where they were done for "private use", and did not require passing any test of fairness. That meant that any such use would be legal, as long as it was for private use. The music publishers' concern was that this would legalize activities of organizations such as church choirs and musical societies that constituted an important market for the sale of music sheets, but whose activities were more likely to be seen as private than commercial, ibid at 282, thus legalizing exactly what had been prohibited in Novello $v$ Sudlow. At the same time, the proposal was narrower because it did not mention research, private study and newspaper summary, and because it contained specific rules covering specific acts with respect to specific types of works. Only criticism and review were subject to a general fair dealing standard. The final version is potentially broader in its scope, although it subjects all such uses to a test of fairness (which might have alleviated the music publishers' concerns), and applied equally to all types of works. 
181 UK, HC, Parliamentary Debates, 5th ser, vol 23 at cc 2587-663 (7 April 1911) $<$ http:/hansard.millbanksystems.com/commons/1911/apr/07/copyrightbill\#S5CV0023P0 19110407 HOC 11>.

182 UK, HL, Official Report, 5th ser, vol 10, c 117 (14 November 1911) <http://hansard. millbanksystems.com/lords/1911/nov/14/imperial-copyright\#column 117>.

183 Ibid.

184 UK, HC, Parliamentary Debates, 5th ser, vol 28 at cc 1951 (28 July 1911) <http:// hansard.millbanksystems.com/commons/1911/jul/28/clause-2-infringement-ofcopyright\#column_1951>.

185 Ibid at cc 1951-56.

186 Ibid (reply of Solicitor-General Sir Simon).

187 Yet British Oxygen, supra note 94 shows that not all judges interpreted the Act in that manner.

188 Burrell \& Coleman, supra note 66.

189 Alexander, supra note 139.

190 Ibid at 283-84.

191 Ibid at 284.

192 MacGillivray, supra note 55 at 27.

193 Deazley, “Commentary", supra note 163. Copinger died in 1910. James Marshall Easton was his son in law. See Will of Walter Arthur Copinger, 1910, online at <http://www.copinger.org.uk/1WA35Will.html>.

194 Copinger on Copyright, 5th ed, supra note 69 at 144 [emphasis added].

195 JB Richardson, The Law of Copyright (London: Jordan \& Son, 1913) at xi. His discussion in the main text is consistent with this observation. For example, in discussing what constitutes an infringement, he summed up explaining that "[c]opyright then consists in the right to prevent an unfair use of the work", ibid at 99. He described how the doctrine on this point evolved and conceded that it is not fully settled, ibid at 100. He then discussed "fair quotation" and noted that extracts were allowed "for the purpose of illustration or criticism", provided it conformed to standards of fairness, ibid at 101 . He devoted an entire section to the notion of "unfair use", explaining that "The question as to what constitutes a fair use of an earlier work is by no means easy to answer; it varies with the nature of the subject, and it has also varied with the same subject from time to time", ibid at 162 . While he clearly disfavoured the notion of fair abridgement, he acknowledged that the law on this point was still unsettled. He took the view that the reasoning in earlier cases allowing fair abridgment did not reflect modern views on copyright, so he was not convinced that courts would necessarily do that. He acknowledged the possibility that courts might "shrink from over-ruling a rule of law laid down so long ago. And possibly so long ago relied on", ibid at 109. Apparently, he did not consider that the absence of 'quotation', 'illustration', or 'abridgement' from s 2(1)(i) - which he discusses only twice, almost in passing (at 37, and 173) - represented any change in the law on fair use.

196 LCF Oldfield, The Law of Copyright (London: Butterworth \& Co, 1912) at 6.

197 Ibid at 57, citing Lawrence v Dana, 4 Cliff 1 at 83 (CC Mass 1869) at 61 ("As a question of strict law, apart from exceptional cases, the privilege of fair use accorded 
to a subsequent writer must be such, and such only, as will not cause substantial injury to the proprietor of the first publication; but cases frequently arise in which, though there is some injury, yet equity will not interpose by injunction to prevent the further use, as where the amount copied is small and of little value, if there is no proof of bad motive, or where there is well-founded doubt as to the legal title, or where there has been long acquiescence in the infringement, or culpable laches and negligence in seeking redress, especially if it appear that the delay has misled the respondent.").

$198 \mathrm{Ibid}$ at 58.

199 Ibid at 18.

$\underline{200}$ Robertson, supra note 166 .

$\underline{201}$ Ibid at 107.

$\underline{202}$ Ibid.

$\underline{203}$ Ibid.

$\underline{204}$ Additional statements are also inconsistent with the conclusion that fair dealing is limited to those purposes. For example, in discussing abridgements, he conceded that the issue was unsettled, and suggested that "whether there is likelihood of competition between the infringing work and the work infringed [would be] an important factor in deciding whether a fair use has been made of the latter or not", without suggesting the fair use is limited to the five enumerated purposes, or noticing that abridgment is not among them, ibid at 106. In discussing parodies, he noted the difficulty that they might present but added that "[i]t has never been suggested, for instance, that the brilliant parody of Tannhäuser was a breach of copyright," without noticing that 'parody' is not mentioned in s $2(1)(i)$, or without arguing that it is a form of criticism, ibid at 112.

205 Copinger on Copyright, 6th ed, supra note 87 at 122.

206 Copinger on Copyright, 5th ed, supra note 69 at 164 . This interpretation would include gratuitous circulation to students. It is clear when this statement is compared to the same author's treatment of gratuitous circulation in the 4th edition. There, in discussing Novello $v$ Sudlow and its progeny, the author explained that " $\mathrm{t}] \mathrm{he}$ gratuitous circulation of copies...is an infringement. And an injunction will be granted to restrain the publication of lithographic copies intended for private use and not for sale or exportation", JM Easton, The Law of Copyright in Literature and Art, 4th ed (London: Stevens \& Hayes, 1904) at 191 [Copinger on Copyright, 4th ed]. The passage from the 5th edition clearly evinces Easton's view that s 2(1)(i) narrows the scope of the holding in Sudlow and permit gratuitous circulation for private study or research, wherein "private" does not mean "copying for one's own use", but is used as the opposite of making available to the public.

$\underline{207}$ Copinger on Copyright, 6th ed, supra note 87 at 123.

208 Harold G Fox, The Canadian Law of Copyright (Toronto: University of Toronto Press, 1944) at 423-25.

209 Ibid at 348-65.

$\underline{210} \mathrm{Ibid}$ at 346. Fox did not offer support for the notion that those terms would be construed strictly, and elsewhere in the book he actually suggested that the term criticism should be given "its broadest sense as meaning a critical use of the material 
for the promotion of the art or science to which it pertains," ibid at 430 .

$\underline{211}$ Ibid.

212 Ibid.

213 Ibid at 425 .

214 Harold G Fox, The Canadian Law of Copyright and Industrial Designs (Toronto: Carswell Co., 1967).

215 John S McKeown, Fox Canadian Law of Copyright and Industrial Designs (Scarborough, ON: Carswell, 2000).

216 Ibid at 439; see also at 546 (referring to the same case law and adding "At the time these cases were decided there were no express exceptions from infringement in the relevant legislation and the concept was linked to whether a substantial part of a work had been taken. This was a common law equitable doctrine which was referred to as 'fair use' or 'fair dealing. Cases dealing with this doctrine must be applied with care.")

217 Ibid at 546-47.

218 Bishop v Stevens, supra note 118. Moreover, since Bishop did not discuss Fox's view or its implications, it cannot be read as repudiation of the view that common law fair use was not abrogated by the legislation.

219 See e.g. Torno, supra note 34 at 71 . See also Judy Erola et al, From Gutenberg to Telidon: A White Paper on Copyright: Proposals for the Revision of the Canadian Copyright Act (Govt. of Canada, Consumer and Corporate Affairs Canada, 1984) at 39-40.

220 Sookman \& Glover, supra note 11 at 153.

221 Barak, supra note 135 at 348-49. It should also be noted that even though the current provision is not identical to the original fair dealing provision from 1921, the changes have been minor, and, with the exception of the insignificant attribution requirements that were added in 1993, all other changes expanded the scope of fair dealing, see supra notes 72-74 and surrounding text.

222 Sullivan, supra note 138 at 201, citing Heydon's Case (1584), 76 ER 637 at 638.

$\underline{223}$ Ibid at 314 .

224 See e.g. William Feilden Craies, A Treatise on Statute Law (London: Stevens \& Haynes, 1911) at 301-03.

225 Supra, note 45 and surrounding text.

226 MacGillivray, supra note 55, at 159-160.

$\underline{227}$ Ibid.

228 This is probably what the Court referred to when it stated in Compo, supra note 20 at 372-73 that "copyright law is neither tort law nor property law in classification, but is statutory law.... This creature of statute has been known to the law of England at least since the days of Queen Anne when the first copyright statute was passed."

229 "Where copyright has been infringed, the owner of the copyright is, subject to this Act, entitled to all remedies by way of injunction, damages, accounts, delivery up and otherwise that are or may be conferred by law for the infringement of a right", Copyright Act, supra note 7, s 34(1). 
$\underline{230}$ Johnstone v Bernard Jones Publications (1937), 1 Ch 599 at 602.

$\underline{231}$ Sullivan, supra note 138 at 314 .

$\underline{232}$ Supra note 180 and surrounding text.

$\underline{233}$ Hawkes \& Son, supra note 17 at 607 (distinguishing between a fair user within the meaning of $s 1$ and fair dealing under s 2(1)(i)).

$\underline{234}$ Alberta (Education), supra note 6, Rothstein J, dissenting.

$\underline{235}$ Compo, supra note 20 at 373.

$\underline{236}$ Théberge, supra note 30 at para 5.

$\underline{237}$ The notion that the "legislation speaks for itself" is rather naïve. "Every text requires interpretation. ... Indeed, the determination that a text's instructions are plain, and thus do not require interpretation, is an interpretive determination that succeeds, rather than precedes, the interpretive act. Characterizing a text as "unclear" is a result of the interpretive process, not an occasion to begin it", Barak, supra note 135 at 12-13. If the statement in Compo ever was true of the Court's attitude toward statutory interpretation, it must have been seriously discredited following the Court's holding in Rizzo Shoes that "that statutory interpretation cannot be founded on the wording of the legislation alone. ... Today there is only one principle or approach, namely, the words of an Act are to be read in their entire context and in their grammatical and ordinary sense harmoniously with the scheme of the Act, the object of the Act, and the intention of Parliament." Rizzo \& Rizzo Shoes Ltd. (Re), [1998] 1 SCR 27 at para $21<$ http://canlii.ca/en/ca/scc/doc/1998/199 8canlii837/1998canlii837.html> [Rizzo Shoes].

$\underline{238}$ Barak, supra note 135 at 7.

$\underline{239}$ Rizzo Shoes, supra note 237.

$\underline{240}$ Ibid.

241 Copyright, Designs and Patents Act 1988 (UK), supra note 128, ss 45-46.

$\underline{242}$ The Copyright Act, however, includes specific provisions permitting acts required to comply with some statutory obligations, see supra note 7 , s 32.1 .

243 $\mathrm{CCH}$, supra note 4 at para 61.

$\underline{244}$ Ibid at para 73 .

$\underline{245}$ Interestingly, the Court's reasoning in para 64 omitted the submission to court proceedings from the quoted policy. The Court reasoned: "The Law Society's custom photocopying service is provided for the purpose of research, review and private study. The Law Society's Access Policy states that '[s]ingle copies of library materials, required for the purposes of research, review, private study and criticism...may be provided to users of the Great Library.' When the Great Library staff make copies of the requested cases, statutes, excerpts from legal texts and legal commentary, they do so for the purpose of research. ... The reproduction of legal works is for the purpose of research in that it is an essential element of the legal research process. There is no other purpose for the copying." The truth, of course, is that there was another purpose for the copying: submission to court proceedings, and the Court must have correctly felt that this act cannot be considered as legal researchsubmissions are typically done after the research, or at least parts of it, has been completed. At the same time, the Court must have realized the absurd consequences for the administration of justice of a rule that required obtaining a copyright owner's 
permission before copies could be submitted to the court and the other parties. It does not seem implausible that if the plaintiff attempted to argue that this aspect of the Library's policy drives it beyond any possible meaning of fair dealing, the Court might have explicitly recognized it as a non-enumerated permissible category; it was wise for the plaintiffs not to raise the issue, and allow the Court to gloss over it. The result, however, is that the Court implicitly recognized this non-enumerated category, even though dealing with the issue in the judgment and recognizing it explicitly might have been a more elegant approach than glossing over it.

246 Sony Corp. of America v Universal City Studios, Inc., 464 US 417 (1984) at 456.

$\underline{247}$ Copyright Act, supra note 7, s 29.23.

248 In some cases it might not be difficult, but in others it might. If the person is an intellectual and the TV show is a discussion on TVO, it might not be difficult to regard the purpose as research or private study. But what about the tired working Canadian who comes home late from work and has more children to attend to and chores to complete than time to watch TV, and makes a recording of the dumbest TV show, in the hope of finding time to turn the brain off for a few minutes and relax? Should this person's user's right not be recognized, or should a court, in order to avoid this absurdity, have no choice but to categorize this activity as research or private study too?

249 "With You - Chris Brown Cover - Justin singing" (11 February 2008) < http:// youtu.be/eQOFRZ1wNLw>.

250 Alberta (Education), supra note 6.

251 Supra part IV.2.

252 Sullivan, supra note 138 at 211.

253 Théberge, supra note 30 . While the Court never reflected on what distinguishes a "just reward" as opposed to an unjust one, the Court's immediate observation that "it would be as inefficient to overcompensate artists and authors for the right of reproduction as it would be self-defeating to undercompensate them", ibid at para 31 , suggests that reward that exceeds what is reasonably necessary to encourage the creator to create in the first place can hardly be seen as just. Such reward is a windfall gain to the owner, which burdens the user and the public.

254 Sayre $v$ Moore, supra note 30.

255 Campbell v Acuff-Rose Music, supra note 33.

256 Royal Commission, supra note 161 at para 67.

257 HR Rep No 94-1476 (1976), at 65 <http://en.wikisource.org/wiki/Page\%3AH.R. Rep._No._94-1476_\%281976\%29_Page_065.djvu > at 65.

258 Hubbard $v$ Vosper, supra note 129.

259 Campbell v Acuff-Rose, supra note 33.

260 Christopher Sprigman, “Copyright and the Rule of Reason” (2009) 7 Journal on Telecommunication and High Tech Law 317 at $327<$ http://law.bepress.com/cgi/ viewcontent.cgi? article $=1207 \&$ context $=$ uvalwps $>$.

261 Martin Senftleben, Copyright, Limitations, and the Three-Step Test: An Analysis of the Three-Step Test in International and EC Copyright Law (The Hague: Kluwer Law Int'l, 2004) at 50-51. 
$\underline{262}$ Peter DiCola \& Matthew Sag, "An Information-Gathering Approach to Copyright Policy" (2012) 34 Cardozo L Rev 101 at 188, 241.

263 Thomas B Nachbar, "Monopoly, Mercantilism, and the Politics of Regulation" (2005) 91 Va L Rev 1313 at 1375.

264 Ariel Katz, "Where Will the Next Google Come From?", Ariel Katz Blog (14 March 2011) <http://arielkatz.org/archives/1000>.

$\underline{265}$ Little Sisters Book and Art Emporium v Canada (Minister of Justice), 2000 SCC 69 at para 236, [2000] 2 SCR $1120<$ http://canlii.ca/t/5239>.

$\underline{266}$ While limited copyright can serve as the "engine of free expression", copyrights that exceed their proper limits can serve as an effective engine for censorship and suppression. See NW Netanel, Copyright's Paradox (Oxford: Oxford University Press, 2008) at 3.

$\underline{267}$ Sookman \& Glover, supra note 11 at 163.

268 DiCola \& Sag, supra note 262.

269 Matthew Sag, Fair Use in the Internet Age (draft manuscript, on file with the author).

$\underline{270}$ Ibid.

271 Supra note 183 . 


\title{
(5)
}

\section{Fairness Found: How Canada Quietly Shifted from Fair Dealing to Fair Use}

\author{
MICHAEL GEIST 11
}

The breadth and scope of copyright limitations and exceptions has emerged as a major policy issue around the world. 2 Some narrow limitations on copyright holders' rights, such as quotation, remain uncontroversial, yet more expansive, flexible exceptions have generated fierce debate. Virtually all domestic copyright laws include some limitations and exceptions to the exclusive rights otherwise granted to copyright holders, typically achieved through the adoption of one of two models.

One approach is a "fair use" model, which is widely viewed as the most flexible limitation and exception on the copyright holders' rights, given its potential applicability to any circumstance or use. As further discussed below, fair use models, which have been implemented in countries such as the United States, Israel and the Philippines, provide an open-ended exception in which any use may qualify as a fair use provided that it meets criteria designed to establish reasonable limits. Those criteria, which seek to adhere to international copyright laws found in the Berne Convention, are either statute-based or developed through case law.

The alternative approach is the "fair dealing" model, commonly 